\title{
Propiedad y pobreza colectiva en san Ignacio y Suárez
}

\author{
Eleuterio Elorduy Maurica S.I. ${ }^{(+)}$
}

\section{Sumario:}

El estudio, escrito en los primeros años 1960 e inédito hasta hoy, trata sobre la pobreza y la propiedad en la tradición jesuita. Tras una breve introducción filosófico-social y una aproximación histórico-jurídica a la cuestión de la pobreza colectiva en la Iglesia, a continuación se trata de la cuestión de los bienes eclesiásticos y exponer de la pobreza en la Compañía de Jesús, para en apartados sucesivos el pensamiento de san Ignacio y el de Francisco Suárez sobre la pobreza colectiva. Unas breves conclusiones, referidas a los primeros apartados no específicamente jesuitas, cierran el estudio. A partir de la espiritualidad y del pensamiento de san Ignacio, recogido en las Constituciones de la Compañía de Jesús y en algunas actuaciones suyas, y de la posición doctrinal de Francisco Suárez con ocasión de la fundación real del colegio jesuita de Salamanca, así como ante la tercera congregación general jesuita en 1608 , el autor concluye que tanto uno como otro concebían la pobreza, y en relación con ella la propiedad, de acuerdo con la doctrina común de la Iglesia de entonces, aunque superando la tensión entre institucionalistas y funcionalistas. Para ambos, la pobreza de la Compañía de Jesús es la propia de una institución carismática en la que los bienes son concebidos sólo como instrumentos de Dios. A ese fin -el de ser meros instrumentos divinos- tienden tanto la espiritualidad ignaciana como el pensamiento suareciano.

\section{Palabras clave:}

bienes eclesiásticos, funcionalismo, institucionalismo, pobreza, propiedad, Suárez

\begin{abstract}
:
This study, from the early years 1960 , and unpublished until now, is about the poverty and the property in the Jesuit tradition. After a brief philosophic-social introduction and a historic-juridical approach to the problem of the collective poverty in the Church, he tackles collective poverty. Next, the issue of the ecclesial possessions is treated and also of the poverty in the Society of Jesus, to come to treat in successive sections about Saint Ignatius' thought on the collective poverty and the thought of Francisco Suárez. Some brief conclusions, referred to the first sections not specifically Jesuits, conclude the article. Starting from the spirituality and from the thought of Saint Ignatius, contained in the Constitutions of the Society of Jesus, and in some of his proceedings, and from the doctrinal positions of Francisco Suárez on the occasion of the foundation of the royal Jesuit College of Salamanca, and also facing the $3^{\text {rd }}$ General Congregation, in 1608, the author comes to the conclusion that both Saint Ignatius and Suárez understand poverty, and related to it, the property, according to the common teaching of the Church of the time, although overcoming the tension between institutionalists and functionalists. To both, poverty in the Society of Jesus is a charismatic institution, in which the possessions are conceived only as instruments of God. To that end, -to be mere divine instruments,- are oriented both the Ignatian spirituality and the suarezian thinking.
\end{abstract}

\section{Keywords:}

ecclesial possessions, functionalism, institutionalism, poverty, property, Suárez 


\section{Propiedad y pobreza colectivas en san Ignacio y Suárez ${ }^{1}$}

1. La pobreza colectiva en la formación de la Iglesia

a) Estilos de pobreza. Institución y función

La pobreza evangélica. tiene diversos estilos. Hay un estilo teológico, básico, característico de toda pobreza cristiana, que consiste en renunciar a los bienes de la tierra por Dios y por los bienes eternos:

"omnis qui reliquerit domum, vel fratres, aut sorores, aut patrem, aut matrem, aut uxorem aut filios, aut agros propter nomen meum, centuplum accipiet, et vitam aeternam possidebit"

Llamamos teológica a este género de pobreza. Evangélica para contradistinguirla de la pobreza de los filósofos que renunciaban a las riquezas por el motivo ascético de la liberación espiritual. La pobreza teológica es una especie de negociación con los talentos recibidos del Señor.

Pobreza cristocéntrica es la que describe san Pedro en dos palabras: "Ecce nos reliquimus omnia, et secuti sumus te"3. Innumerables almas religiosas siguen la pobreza de Cristo, sin más aspiración que la del amor. San Pedro de Alcántara reprobaba a santa Teresa que sobre esto hubiera consultado a los

${ }^{1}$ En el Archivo Suáreciano se encuentra este trabajo con la referencia A5-E, 14 mecanografiado en 43 páginas folio precedidas de la siguiente nota.

"Este trabajo está ya censurado y aprobado por los censores de la Provincia. Uno de los censores indicó que se debía enviar al M.R.P. General, como se hizo en el mes de febrero de 1962, a fin de obtener la licencia para la publicación. Todavía no se ha obtenido ninguna respuesta. El R.P. Greco, canonista del Instituto Católico de Paris, lo leyó y fué de parecer que el autor urgiera a Roma una contestación rápida para la publicación.

Posteriormente lo leyó el R.P. Yanguas, ex-Decano de la Universidad Pontificia de Salamanca, y por creerlo completamente perfecto y útil sacó por su cuenta algunas copias, de las cuales ha dado alguna a una Superiora General de una orden religiosa, y ha manifestado así mismo el deseo de que el trabajo sea cuanto antes comunicado a la Sagrada Congregación de Religiosos por la importancia de los puntos que en él se desarrollan. La autoridad del R.P. Yanguas es reconocida por la jerarquía española y también muy especialmente por los opositores a canongías, quienes utilizan los apuntes muy extensos y eruditos de Derecho Canónico del R.P. Yanguas, que no los ha podido publicar todavía por falta de recursos económicos. El trabajo ha sido también leído por otros teólogos, aun cuando en número muy restringido".

Quede constancia de nuestro agradecimiento al profesor Juan Antonio Senent de Frutos por facilitarnos el manuscrito. La presente edición se integra en el proyecto de investigación PEMOSJ del Ministerio de Economía y Competitividad y del Fondo Europeo de Desarrollo Regional (FEDER). Código de proyecto FFI2015-64451-R (MINECo/FEDER).

\footnotetext{
${ }^{2}$ Mat 19, 29

${ }^{3}$ Mat 19, 27
} 
letrados ${ }^{4}$. Estos le aconsejaron que tomara rentas para sus conventos. El P. Ibáñez envió "dos pliegos de contradicción y teología para que no lo hiciese, y así me decía que lo había estudiado mucho". Pero en tornando a la oración y mirando a Cristo desnudo y pobre, "no podía poner a paciencia ser rica"5.

El estilo de la pobreza colectiva o corporativa tiene por finalidad, no sólo el seguimiento de Cristo, sino la función de la Iglesia, como en los apóstoles, que son miembros o sarmientos de Cristo, que es la Cabeza y la vid, e instrumentos del Espíritu Santo. Los miembros nada poseen; todo es de la Cabeza o la persona total. Ellos son instrumentos. En palabras, que lo mismo pueden referirse a la época nueva de la formación de la Iglesia que al reino escatológico, describe Cristo la índole de esta pobreza apostólica y eclesial:

"vos qui secuti estis me, in regeneratione, cum sederit Filius hominis in sede maiestatis suae, sedebitis et vos super sedes duodecim iudicantes duodecim tribus Israel".

Los apóstoles no negocian con los talentos, sino que juzgan en la Iglesia fundándola.

La primitiva comunidad de Jerusalén comenzó a practicar esta pobreza apostólica y eclesial, Los fieles vendían los bienes y dejaban el producto a los pies de los apóstoles. Los fondos los repartían "prout cuique opus erat". Así resultó aquella comunidad carismática:

"Multitudinis autem credentium erat cor unum, et anima una: nec quisquam eorum, quae possidebat aliquid suum esse dicebat, sed erant illis omnia communia"s.

La pobreza comunitaria tenía, por lo tanto, una finalidad fundacional procurando la gloria de Dios, aunque eran libres para seguir con los bienes, como Ananías y Safira. La pobreza colectiva es la que principalmente interesa a san Ignacio como fundador y a Suárez como teólogo. Por supuesto, la transformación de la propiedad privada en comunidad de bienes, como advierte Suárez, no impedía que la renuncia fuera hecha a Dios. Más bien, la total renuncia de los bienes hecha a Dios tiene como consecuencia connatural que estos adquieran un carácter común:

${ }^{4}$ Teresa de Jesús, Obras (Relaciones espirituales), Burgos 1915 Biblioteca Mística Carmeliana (BMC 2, 125)

5 Teresa de Jesús, Obras (Libro de la vida), Burgos 1915 (BMC 1, 297)

${ }^{6}$ Mat 19,28

${ }^{7}$ Ac 4,35

${ }^{8}$ Ac 4,32 
"Quamquam enim bona, quae a particulari persona relinquuntur, a communitate possideantur, hoc non tollit quin veram oblationem suorum bonorum Deo faciat, quia seipsum privat dominio illorum, et iure utendi, et administrandi illa proprio nomine et auctoritate"

Es importante observar cómo convergen en la pobreza cristiana tres dominios esencialmente distintos: el dominio humano de propiedad, el dominio de Dios que acepta los bienes renunciados en su honor y el dominio de utilidad comunitaria. El paso del derecho humano al derecho divino no es un resultado necesario y natural de la renuncia voluntaria. Lo natural es que los bienes renunciados sin sujeto humano que los acepte, se transforman en bienes vacantes o mostrencos primi capientis. Dios acepta la renuncia hecha por medio de Cristo, como realización de la doctrina evangélica por iniciativa expresa de Cristo, que tiene el dominium excellens sobre todos los bienes y personas para restaurar en el mundo el reinado de Dios conforme a sus designios soberanos. En su análisis del sistema económico de la pobreza apunta Suárez otro concepto fundamental, que es el de la administración eclesiástica, que surge en los comienzos de la Iglesia.

El reparto irregular de los bienes necesarios dió lugar al "murmur Graecorum adversus Hebraeos"10, ocasionado por el trato desfavorable sufrido por las viudas griegas. Los apóstoles eran directa o indirectamente objeto de las protestas, pero venciendo los intereses de su amor propio y de su nacionalismo, instituyen el diaconado, como corporación administrativa de la Iglesia, para desentenderse ellos de las solicitudes de los bienes de la Iglesia. Humanamente esta medida parecía un contrasentido. La libre disposición de renuncias importantes de miles y miles de fieles ponía en sus manos un prestigio económico-social de gran valor propagandístico con medios de organización importantes para rodear el nombre del Maestro resucitado de una notoriedad y gloria apta para la difusión del cristianismo. ¿No era precisamente ese poder humano la causa de sus discusiones mutuas en el seno del Colegio apostólico? Iluminados ya por el Espíritu Santo no recayeron en la funesta tentación de apoyar con el poder económico la autoridad apostólica recibida de Cristo. La estructura de las comunidades primitivas, comparada a veces con el socialismo y el comunismo, se diferencian socialmente de ellas en que no centraliza la propiedad ni la administración, fusionando la autoridad con el poder económico. Con un despego absoluto de los bienes terrenos,

\footnotetext{
${ }^{9}$ De religione tr. VII lib. 8 c. 2,$19 ; 15,554$.

${ }^{10}$ Ac 6,1
} 
renunciaron no sólo a la propiedad sino aún a la administración directa de los bienes comunitarios, salvando así el prestigio del apostolado, como verdaderos jueces salvadores de la Iglesia. Sólo en ocasiones especiales y con todas las cautelas para que el misterio del apostolado "ne vituperetur in hac plenitudine, quae ministratur a nobis" 11 se ocupa san Pablo de los problemas económicos de la propiedad y pobreza de la Iglesia. San Pedro llama la atención de los jerarcas acerca de los tres vicios básicos que deben evitar: "pascite gregem Dei, providentes non coacte, sed spontanee secundum Deum, neque turpis lucri gratia sed voluntarie: neque ut dominantes in claris sed forma facti gregis ex animo" 12 .

Estos datos reflejan en su mismo origen la variadísima problemática de la pobreza evagélica y cristiana, en combinación unas veces, y otras veces en oposición con las exigencias de la propiedad individual y colectiva. Las alteraciones de combinación y oposición se producen especialmente en las manifestaciones institucionales y funcionales características de la propiedad y de la pobreza eclesiástica. La tensión entre ambas tendencias, siempre fuerte en la vida humana, se agudiza en las épocas de las grandes crisis y revoluciones, En la Iglesia primitiva prevaleció tal vez lo funcional, pero no con un predominio absoluto, pues el diaconado representa la necesidad de una institución permanente de administracion regular e irreprensible. Más aún, la expresión de que los fieles eran "cor unum et anima una" ${ }^{13}$ refleja una tendencia funcional de la Iglesia como institución corporativa, es decir como una vinculación que ha de gozar por la acción continuada del Espíritu Santo de una realidad permanente, independiente de los cambios funcionales de cada momento histórico.

El institucionalismo halló su expresión doctrinal en el concepto paulino del cuerpo místico de Cristo, dividido en órganos dotados de su función respectiva. De todas maneras es indudable la tensión que siempre ha habido entre el aspecto permanente y normativo de lo institucional y la tendencia hacia la eficacia máxima propia de lo funcional. San Ignacio vivió esa tensión en una de los momentos más álgidos de la lucha entre el funcionalismo carismático promovida por los protestantes y la defensa de las instituciones amparadas por la Iglesia católica. Especialmente en el tema de la pobreza, Suárez defiende contra los protestantes su aspecto institucional representado en los votos religiosos.

La oposición entre ambas tendencias tal vez nunca ha sido tan profunda y universial, aún dentro del catolicismo, como en nuestros días.

\footnotetext{
${ }^{11} 2$ Cor 8,20 "devitantes nos, ne quis nos vituperet..."

121 Petr 5,2s

${ }^{13}$ Ac 4,32
} 
El progreso de la técnica y el derrumbe de las estructuras medievales han transformado la vida política y civil amenazando suprimir toda huella de institucionalismo. Una corriente vertiginosa, cada vez más intensa, azota las estructuras heredadas de la historia. La familia, el municipio, el Estado comienzan a parecer preocupaciones utópicas y sin consistencia ante el huracán funcionalista polarizado en la existencia individual de cada uno y en la pervivencia material de la especie humana, con exclusión de todas las estructuras intermedias.

La propiedad, sin renunciar al egoísmo instintivo del goce individual, interesa como puro instrumento del goce momentáneo de la vida, no como una institución permanente de las estructuras sociales. El patrón oro ha cedido ante la superioridad del crédito sobre el capital acumulado, y el mismo crédito se parapeta en último término en el poder individual o colectivo de ocupación y de conquista. ¿Qué significan ante la avalancha funcional moderna los cercados minúsculos con que los siglos pasados defendían los límites de sus fincas o las claúsulas fundacionales de una entidad cualquiera? Aun fuera del comunismo, en el mundo capitalista va perdiendo terreno la institución de la propiedad, y con ello cambia también el concepto correlativo de la pobreza, que se trata de funcionalizar.

El criterio funcionalista de la pobreza podrá aún confirmar sus posiciones con el mismo Evangelio. La pobreza es eminentemente funcional en cuanto se basa en la garantía del poder divino. El pobre voluntario, en el lenguaje de los Padres, contaba con la fe de que Dios era su ecónomo y sostén. Era una pobreza apoyada en un poder infinito. Los progresos inmensos de la ciencia hacen hoy innecesaria la intervención milagrosa de Dios en el curso normal de la vida. La pobreza debe transformarse en laboriosidad austera e inteligente, que tiene para el hombre moderno las ventajas ascéticas que para el antiguo tenía la renuncia al mundo.

Tales son en síntesis los argumentos verdaderos o falsos con que el funcionalismo moderno, impugna, aun dentro del pensamiento católico, la pobreza institucionalmente practicada. Sólo hay que observar el equívoco en que se fundan varias de estas razones. La pobreza evangélica como institución nunca se compara con la riqueza en la eficacia natural y humana. La riqueza goza de un poder natural que hoy y siempre le ha hecho dueña del mundo, hasta el punto de contraponerse en el evangelio el servicio de la riqueza con el servicio de Dios. Entre las razones que San Ignacio pone en la balanza a favor de las rentas y de la renuncia a ellas, todos los motivos de la eficacia humana están en el platillo de las rentas. No se trata de la gloria externa y políticosocial, que buscan los hombres, sino de la que quiere el mismo Dios. ¿Dónde se halla ésta? ¿En lo funcional o en lo instítucional?. 
En los pocos estudios dogmáticos dedicados al tema actual de la pobreza se ha llegado a la convicción de que se trata de un problema que afecta a la esencia de la Iglesia. Recojamos la importante afirmación de Karl Rahner:

"No se debe olvidar en la Teología de la pobreza, que en la pobreza de una orden religiosa se ventila un momento de la vida de una comunidad que se identifica con la realidad tangible histórica y comunitaria de momentos esenciales de la Iglesia" ${ }^{14}$.

Poco antes había estudiado el tema en su perspectiva internacional cristiana F. Russo ${ }^{15}$.

\section{b) La pobreza colectiva constitutiva de la Iglesia}

Partamos de esta misma observación. El tema de la pobreza evangélica comunitaria, aun fragmentariamente considerado, afecta a la esencia de la Iglesia toda. Por eso el problema de la pobreza de las órdenes religiosas no puede ser indiferente a los teólogos ni a la jerarquía. San Ignacio vió la conexión entre la pobreza de la Compañía, la de la Iglesia y la de Cristo, al formular la razón tercera en favor de la pobreza de la Compañía:

"Parece que con mayor afecto se une con la Iglesia, siendo uniformes en no tener cosa alguna, considerando en el Sacramento a Cristo pobre" 16 .

A la teología toca fijar el alcance dogmático de la expresión ignaciana sobre la pobreza colectiva de la Iglesia. En ella preside Jesús sacramentado, desprovisto de todo y puesto a disposición de todos. En el templo cristiano el pobre más necesitado tiene tantos derechos o más que el rico más opulento. Los tratadistas no parecen haberse preocupado mucho del tema de la pobreza colectiva, que sólo mencionamos aquí para hacer honor a su importancia, diversa según los diversos sistemas de propiedad practicados en las órdenes religiosas.

Siguiendo al padre Gutiérrez se puede establecer en ellos la siguiente clasificación: Hay un tipo de propiedad colectiva de plena autonomía de cada

${ }^{14}$ K. Rahner, "Die Armut des Ordenslebens in einer veränderter Welt": Geist und Leben 33 (1960) 268

${ }^{15}$ F. Russo, "La pauvreté devant les transformations économiques et sociales du monde «moderne»": Christus 24 (1959) 437-499

${ }^{16}$ Ignacio de Loyola, "Deliberación sobre la pobreza" (autógrafo de 1544) en Obras completas, Madrid ${ }^{2} 1963$, Católica (BAC 86) 298. 
casa o persona moral: tal sucede en los monasterios antiguos, cuyos bienes son absolutamente intransferibles y exclusivos de cada monasterio. Un segundo sistema de autonomía se da cuando el dominio de los bienes de cada casa excluye la transferibilidad, pero admite las cargas de obligaciones comunes de representación y gobierno, como entre los Dominicos y Premostratenses y, en grado más limitado, en la Compañía. Un tercer sistema es el de la autonomía coordinada, donde las casas disponen de una parte de sus bienes, reservando un tanto por ciento para la congregación. El cuarto sistema es el de la autonomía coordinada y subordinada; se da este sistema cuando las casas administran sus bienes pero contribuyen con cargas ilimitadas a las obras comunes según cálculos fijados para cada ejercicio económico. Es un sistema centralista, del que son una variante la organización de la Sociedad del Verbo Divino y de los Claretianos. De los Claretianos dice el padre Gutiérrez que el superior mayor goza de potestad para trasladar los bienes de una persona moral a otra. El mismo autor propugna que este sistema no es contrario al derecho canónico $\mathrm{y}$ es conforme a las ordenes centralizadas ${ }^{17}$. Finalmente hay un sistema de propiedad centralizada donde la orden o la congregación es propietaria de todos los bienes de sus casas o personas morales no colegiales.

Tales son los esquemas de la propiedad eclesiástica de las personas morales no colegiales, a los que corresponden diversas clases de pobreza constitucional colectiva. El criterio de diversificación de estos esquemas lo ha fijado el autor en la intransferibilidad aun de los bienes muebles. Sería interesante acoplar ese esquema al de los estilos eclesial y teológico que indicamos al principio. Por ahora nos faltan elementos para esa comparación. Hagamos dos observaciones.

La intransferibilidad se opone al centralismo personalista, es decir al poder de personas privadas o públicas, incluso de personas morales colegiales, para detentar la propiedad de tales bienes o su administración arbitraria. Tanto la intransferibilidad como el centralismo tiene sus ventajas y desventajas. Cada uno de los sistemas constituye un todo harmónico vital, como las especies animales que se defienden unas volando y otras atacando. Un ejército no centralizado es una masa caótica. Una nación centralizada es un pueblo deshecho por la tiranía. Hay órdenes que necesitan el centralismo para su actividad rápida y modificable en pro del bien común. En cambio, la intransferibilidad de los bienes eclesiásticos va acompañada de su carácter comunitario, y ambos rasgos provienen de la entrega absoluta de tales bienes hecha a Dios. Al ser aceptada la renuncia

${ }^{17}$ A. Gutiérrez, "De capacítate acquirendi et administrandi personarum moralium in religione": Comentarium pro religiosis 31 (1952) 23 
total evangélica y quedar los bienes libres de toda propiedad humana, quedan en manos del Creador y por lo tanto a disposición de todos los que sean capaces de usar de ellos.

Este punto es digno de consideración. Los apóstoles y los fieles de la Iglesia primitiva se hubieran asombrado si alguien con visión profética les hubiera vaticinado que a los diecinueve siglos de lucha y expansión, la Iglesia de Cristo, constituida por centenares de millones de propietarios más o menos ricos, se encontraría enfrentada con un poder enemigo promotor del comunismo económico. Entre el totalitarismo imperial romano y el totalitarismo político de ese enemigo futuro de la Iglesia, tal vez no hubieran advertido demasiadas diferencias, pero la mentalidad de propietarios conservadores les hubiera parecido una novedad y acaso un contrasentido para los cristianos.

Condenado el capitalismo, ¿qué hubieran preferido?, ¿la pobreza colectiva institucional de entidades industriales o económicas comunitarias administradas por individuos o por corporaciones, o más bien el régimen actual de la propiedad? La respuesta habría que formularla con el criterio del evangelio y de la acción del Espíritu Santo manifestada a través de la historia. Como cristianos debemos pensar que el posible, y no sabemos si cercano, cataclismo comunista no tiene sentido anticristiano en su puro aspecto económico. Cristo se abstuvo expresamente de intervenir en pleitos de propiedad ${ }^{18}$, que para nada interesan al mensaje evangélico. El comunismo es anticristiano por ser ateo y por sus métodos violentos.

La ciencia actual tiene recursos suficientes para ir pensando e implantando estructuras económico-sociales cristianas, aptas para la prosperidad de los individuos y de los pueblos, libres tanto de la centralización socialista de poderes dictatoriales, como de la lucha social de todos contra todos en el régimen actual de la propiedad, tal como ha sido configurado por el capitalismo liberal.

El planteamiento de la cuestión, que al principio se nos presentó como oposición entre el institucionalismo antiguo y el funcionalismo moderno se presenta en realidad más bien como oposición entre el poder central de una persona física o colegial y la intransferibilidad propia de los bienes cedidos a Dios y al bien común. La pregunta sobre la propiedad colectiva recae también sobre la administración de los bienes. En último término se pregunta si la propiedad y administración de los bienes eclesiásticos depende de normas permanentes de las fundaciones o personas morales no colegiales, o del poder centralizador y voluntad de los gobernantes.

\footnotetext{
${ }^{18} \mathrm{Lc} 12,13 \mathrm{~s}$
} 
Por una parte se hace duro pensar en las consecuencias de la intransferibilidad de los bienes eclesiásticos o religiosos. ¿Es posible que la donación de un inmueble hecha en un momento de la historia por un donante desconocido haga intangibles esos bienes en la sucesión de los siglos, dejándolos tal vez improductivos en las manos muertas de los que los administran?

Mas por otra parte, ¿cómo justificar un cambio hecho en bienes aceptados por Dios, si es que los acepta? y ¿cómo justificar, aun ante los hombres, ese cambio, si Dios acepta los bienes para un fin comunitario? Existe en la tierra un poder capaz de realizar cambios de sujeto de propiedad y de transferencia de bienes aceptados por Dios para un fin determinado? Supongamos que alguien hubiera propuesto a san Pablo con razones al parecer convincentes la necesidad más urgente de los fieles de Damasco y la oportunidad de transferir a ellos las limosnas recaudadas para los fieles de Jerusalén, o que se le hubiera sugerido la gloria inmensa derivada para Cristo y su Iglesia del establecimiento de una especie de Qumran cristiano en Alejandría para la formación de numerosos alumnos sucesores de los apóstoles. ¿Se hubiera creído autorizado para cambiar el destino de las sumas recaudadas? Lo que se dice de san Pablo y de los apóstoles, hay que aplicarlo a la Iglesia.

La solución en definitiva depende ante todo de la verdad dogmática de la aceptación divina de los bienes renunciados por el hombre para seguir los consejos evangélicos. Puesta esta aceptación real e incondicional, hecha sólo por los individuos, surge la pobreza individual; y si la renuncia es también colectiva, como lo fue en los apóstoles, surge la pobreza colectiva. Si se admite la aceptación como divina e incondicional, los bienes quedan bajo el dominio exclusivo de Dios, que es dominio transcendente propio de la Causa Primera.

Nos hallamos, por tanto, ante este dilema: los bienes son propiedad de un poder central o son intransferiblemente del dominio transcendente de Dios. Es preciso que examinemos bien las consecuencias de una solución o la contraria. Si Dios acepta los bienes de una renuncia individual o colectiva, estos salen de la órbita de la propiedad humana y entran en la esfera del dominio transcendente de Dios.

Obsérvese que todo ser inferior que entra en la órbita de un ser superior, se acomoda a la actividad del ser superior en forma de satélite, de parte integrante o de instrumento. Esto ocurre en el electrón integrado en el átomo, en el átomo absorbido por la molécula, en ésta al ser incorporada a la célula, en la célula al constituir un tejido u organismo. El cuerpo informado por el alma pierde su independencia y es puro instrumento del alma. 
No es indiferente para los bienes y personas que renuncian a su propiedad y autonomía, el que entren directa y exclusivamente en la órbita del dominio transcendente de Dios o se incorporen a un poder humano individual o corporativo, que se adueñe de ellos y los administre como propios. En el primer caso, suponiéndolo posible y real, los bienes y personas son instrumentos de la acción de Dios en la fundación o integración de la Iglesia. Dios es la Causa principal de su actividad en la Iglesia. Ellos son sólo causas instrumentales. En el caso segundo son causas subordinadas pero principales de su actividad, que participa ocasionalmente en la vida de la Iglesia. Volviendo, por lo tanto, a los tres tipos de la pobreza cristiana, los bienes intransferiblemente entregados a Dios constituirían la pobreza eclesial y contribuirían directamente a la formación de la Iglesia. En cambio, los bienes centralizados por un superior o por una curia religiosa, constituirían la renuncia propia de la pobreza teológica y serían medios externos y ocasionales a la vida de la Iglesia y contribuirían como tales.

No se trata de discutir cuál de los sistemas es de mayor gloria divina. Es posible que un maestro seglar, que enseña en una escuela estatal, por su espíritu y celo individual ejerza una acción religiosa muy superior a la de un profesor de un centro religioso y aun a la de un predicador y confesor, aunque estos desempeñen una actividad eclesial y el maestro estatal desarrolla sólo una actividad individual profundamente religiosa. El caso es semejante al de la inspiración bíblica y no bíblica. San Juan de la Cruz y santa Teresa son autores principales de obras inspiradas, pero no con inspiración bíblica. En cambio, los hagiógrafos bíblicos son solo instrumentos de Dios, causa principal de la Biblia. Esto no implica que cualquier libro del antiguo o del nuevo testamento contribuya a la gloria de Dios más que los escritos místicos de santa Teresa.

No se trata pues, de saber cuál de los sistemas de pobreza es el más beneficioso para la Iglesia, sino sólo determinar si son pobrezas esencial o realmente diversas. Tampoco se pregunta si el sumo pontífice puede hacer que una orden pueda pasar de un sistema a otro, sino si estos sistemas son en mismos equivalentes o intrínsecamente transformables. El tema de la extinción de las personas morales o de las instituciones por causas internas o externas, naturales o violentas, es una cuestión diversa, que aquí no se discute. Nuestro problema dogmático positivo trata de investigar si hay una pobreza eclesial institucionalmente creada en el evangelio o en la Iglesia apostólica, es decir si tal pobreza es de institución divina, o por lo menos apostólica. En ambos casos se supone, aunque muchos lo niegan, la realidad de los entes jurídico-morales, y en especial de las personas e instituciones eclesiásticas, cuestión que ampliamente hemos tratado en otros trabajos. 
La propiedad y la pobreza colectiva son, según esto, dos instituciones, que afectan directamente al dominio de los bienes materiales e indirectamente al de los bienes espirituales y jurídico-morales, como la autoridad.

Esquemáticamente podríamos representar los sujetos distintos, objetos y zonas diversas del dominio y de la causalidad que en ellos se desarrollan, en el cuadro siguiente:

\begin{tabular}{|l|l|l|l|l|}
\hline \multicolumn{1}{|c|}{ Dios } & \multicolumn{1}{|c|}{ Cristo } & \multicolumn{2}{c|}{$\begin{array}{c}\text { Administradores de Dios } \\
\text { I }\end{array}$} & \multicolumn{1}{c|}{$\begin{array}{c}\text { Propietarios } \\
\text { II }\end{array}$} \\
\hline $\begin{array}{l}\text { Dominubordinados } \\
\text { transcendente } \\
\text { de todos los } \\
\text { bienes: materiales, } \\
\text { espirituales y } \\
\text { jurídico-morales }\end{array}$ & $\begin{array}{l}\text { Dominium } \\
\text { excellens de } \\
\text { todos los bienes } \\
\text { materiales, } \\
\text { espirituales y } \\
\text { jurídico-morales }\end{array}$ & $\begin{array}{l}\text { Administración a } \\
\text { título de causas } \\
\text { instrumentales } \\
\text { sobre bienes: } \\
\text { a) materiales } \\
\text { b) espirituales } \\
\text { c) jurídico-morales }\end{array}$ & $\begin{array}{l}\text { Administración a } \\
\text { título de causas } \\
\text { principales: } \\
\text { a) materiales } \\
\text { b) espirituales } \\
\text { c) juridico-morales }\end{array}$ & $\begin{array}{l}\text { Uso y abuso } \\
\text { arbitrario sobre } \\
\text { los bienes todos: } \\
\text { a) materiales } \\
\text { b) espirituales } \\
\text { c) jurídico-morales }\end{array}$ \\
\hline \multicolumn{3}{|c|}{ Zona superpredicamental: } & \multicolumn{2}{|c|}{$\begin{array}{l}\text { Zona predicamental: } \\
\text { el hombre causa principal }\end{array}$} \\
Dios causa principal
\end{tabular}

Para nuestro tema nos interesan las columnas I y II de los administradores de Dios. Supuesta la realidad de los entes morales (naturales y sobrenaturales), ambas columnas responden a vidas diversas. No se puede pasar arbitrariamente de la columna I, propia de quienes han devuelto a Dios todos los bienes recibidos para ser instrumentos de su voluntad por medio de Cristo, a la columna II de los que negocian libremente a gloria de Dios con los talentos de Él recibidos. Ananías y Safira intentaron trágicamente el empleo simultáneo de uno y otro sistema.

Por lo demás, como se ve por el cuadro, la propiedad es un concepto estrictamente sólo aplicable a Dios, que falsamente se atribuyen a sí mismos, los llamados propietarios insubordinados. El concepto auténtico cristiano es el de la administración en una u otra modalidad. El concepto romano de propiedad, como capacidad moral de uso y abuso de las cosas, es insostenible $\mathrm{y}$ ha sido superado por el cristianismo. Resulta imprescindible en el concepto auténtico tener presente esta superación del concepto de propiedad realizada por el cristianismo. Para ello creemos útil espigar unos datos, que permitan fijar el concepto romano de propiedad colectiva para compararlo con el concepto correspondiente de la administración de los bienes comunes en el cristianismo ${ }^{19}$.

${ }^{19}$ Véanse nuestros artículos: "La realidad jurídico moral. Esquema histórico": Anales de la Cátedra Francisco Suárez (Universidad de Granada) 1 (1961) 3-29; "Persona e Institución": Estudios de Deusto, 7 (1959) 13-47 y "La Moral Suareciana": Anuario de la Asociación Francisco de Vitoria 6 (1943/5) 97-189. 
No vamos a seguir el procedimiento que siguió o pudo seguir esta figura jurídica y carismática al mismo tiempo, hasta llegar a su plena madurez. Un proceso paralelo y convergente se operó precisamente en los siglos primeros de nuestra era con las propiedades y bienes de los collegia, cuya evolución podemos seguir por estar mejor documentada ${ }^{20}$.

\section{La propiedad colectiva}

Los romanos consideraban a la civitas no sólo como sujeto de derechos y obligaciones (o persona) capaz de dominio de propiedad, sino también como persona suprema y divina capaz de otorgar personalidad a los collegia estatales fundados para el bien común. En cambio, las societates de carácter privado (collegia illicita) eran considerados como personas sólo por sus miembros; no gozaban de ese rango ante la civitas y los demás ciudadanos. Los fondos del erario público estatal o municipal y las arcae de los colegios públicos eran indivisibles. Era absurdo pensar que se pudieran dividir entre los ciudadanos o los socios respectivos que nunca podían ser considerados como dueños de los fondos comunes. Eran sólo administradores o síndicos de los mismos. En cambio, los socios de los colegios privados sólo consideraban como indivisibles su arca común, mientras no se disolviera el colegio privado del que formaban parte. En caso de disolución del colegio, los bienes colegiales eran repartidos entre los socios.

El emperador Marco Aurelio parece haber sido más generoso en permitir la formación de colegios autorizados por el Estado y con ello el derecho de propiedad colectiva:

"Paulus libro duodecimo ad Plautinum: cum Senatus temporibus divi Marci permiserit Collegiis legare, nulla dubitatio est, quod si corpori cui licet coire, legatum sit debeatur; cui autem

\footnotetext{
${ }^{20}$ Sobre el alcance práctico del tema, conviene tener presente que el paso de un sistema institucional a otro (prescindiendo de la intervención directa del legislador, que aquí es Cristo o los Apóstoles o el Papa) no se puede realizar por vía de interpretación de la voluntad de los donantes. Como advierte Suárez, "satis non erit interpretativa voluntas praedicto modo explicata quia revera nulla est, ut dixi in materia de confessione, si ad valorem actus necessaria sit iurisdictio a Superiore collata, non sufficit praedicta interpretatio, sed necesse est ut aliquo modo constet de superioris voluntate" (De voluntario Disp. I s. 4; 4, 174) Cfr. De poenitentia Disp. 26, s. 6,5; 22,555). Un administrador instrumento de Dios (columna. I) no puede proceder por vía interpretativa como si fuera causa principal. Si lo intenta, su decisión no sólo es de insubordinado sino de invasor del dominio divino, que cae fuera de la clasificación del cuadro.
} 
non licet si legetur, non valebit, nisi singulis legetur: hi enim non quasi collegium sed quasi homines certi admittentur ad legatum"21.

Los collegia, que hasta entonces habían sido personae incertae por no ser licitae, comenzaban a adquirir una personalidad fija y permanente. Más tarde Severo concedió la misma autorización, muy especialmente y como privilegio, a los collegia fundados por motivo de culto a dioses de las provincias: "sed religionis causa coire non prohibebatur" 22 . Según Kornemann ${ }^{23}$ se permitía hacer donaciones y legados, aun de bienes inmuebles, a estos colegios, "sehr oft in der Form, dass die Schenkung dem Schützgotte des Collegium (deo... et collegio) der dem ersteren zur Ehre des collegium (in honorem collegii) gemacht wurde, indem diesse Consecration, wenn auch nicht rechtlinch, so doch thatsächlich, den betreffenden Objekten einen sakralen Charakter verlieh, der sie gegen Missbrauch und Rückforderung schützte..." "Diesse Collegien, welche frei über ihr Vermögen verfügten, konnten wie einzelne Personen aktive und passive Verpflichtungen eingehen, konnten Schüldner und Gläubiger werden" 24 .

La raíz última de la dificultad en ser sujetos de derechos y de obligaciones estaba, por consiguiente, en constituir entidades o personas ciertas ante la ley, es decir determinables y capaces de acción ante los tribunales. Ahora bien, la causa religionis era un título que servía para la obtención de esa individualización o personalidad determinada, dejando de ser persona incerta, corpus incertum. Ambas denominaciones son equivalentes conforme a la noción jurídica de persona y a la filosofía de los estoicos, para los que "corpus est id quod facit aut quod fit". Gayo dice de las personas o cuerpos indeterminados:

"Incertae personae inutiliter relinquitur. Incerta autem videtur persona, quam per incertam opinionem animo suo testator subicit" 25 .

${ }^{21}$ Cfr. E. Kornemann. “Collegium” en Pauly-Wissowa, Realenencyclopädie (RE) 430; Digesto 34, 5, 20.

${ }^{22}$ Digesto 47, 22, 1

${ }^{23}$ Cfr. E. Kornemann., cit., 432

${ }^{24}$ Ibid.

${ }^{25}$ Gaii institutiones 2, 238, edición de A. d'Ors Pérez-Peix, Madrid 1943, 99 
La doctrina del dominio transcendente de Dios, básica en el cristianismo, aunque no siempre vivida con la intensidad debida, proporcionó a los emperadores cristianos un elemento nuevo para promover la determinación de las personas colegiales en los donativos y legados hechos por motivos religiosos.

El año 405 ordenó Honorio que las fincas detentadas por los donatistas fuesen devueltas a la Iglesia católica, es decir a los obispos respectivos. Era una medida adoptada en el siglo anterior, sin resultado positivo, por los emperadores Valentiniano I y Graciano. El año 416 se ocupó del pleito San Agustín. Los donatistas acusaban a los católicos en particular por haberse incautado de una granja donada por Gayo Seyo a la iglesia presidida por el donatista Faustino. Su acusación se basaba en el principio de que los donativos religiosos no pueden desviarse del destino primero y definitivo de los donantes, a no ser por permuta o por venta. San Agustín tiene buen cuidado de no impugnar ese principio. Su argumentación es de tipo defensivo. A los donatistas les pregunta a nombre de quién detentaban las fincas en litigio. Si decían que en nombre de los emperadores, como ocurría dos siglos antes con los collegia licita de los paganos, entonces debían apelar a los emperadores, que habían dado leyes favorables a los católicos. El donatista se rebela contra esta solución y replica: "Sed quid est mihi imperator?". San Agustín responde:

"Secundum ius ipsius possides terram... Vultis recitemus leges et gaudeatis quia vel unum hortum habeatis et non imputetis nisi mansuetudini columbae, quia vel ibi vobis permittitur permanere" 26 .

Según las ideas de su época, san Agustín se apoya, sin discutirla, en una teoría imperialista, conforme a la cual es propio de emperadores y reyes el conceder el ius soli o ius fundi a quien les parezca. Suárez no admite esta doctrina propia del estatismo socialista actual o del cesarismo teocrático de los emperadores paganos. Los reyes sólo poseen un poder de jurisdicción sobre sus reinos, no un poder de dominio de propiedad sobre las tierras de los súbditos. Durante la edad media el ius soli tuvo una importancia muy grande, como veremos, en las aspiraciones de los señores feudales o de los amos sobre los templos construidos en sus posesiones. En cuanto a san Agustín, por encima del poder de los emperadores y de su ilimitado dominio temporal de propiedad, establece otro dominio transcendente de Dios:

${ }^{26}$ San Agustin, Obras completas (vol. 13. Tratados sobre el evangelio de San Juan), Madrid 1955, Católica (BAC); Tratado 6, 25; PL 35, 1436. 
"Divinum ius in Scripturis habemus; humanum ius in legibus regum. Unde quisque possidet quod possidet? Nonne iure humano? Nam iure divino, Domini est terra et plenitudo eius (Salmo 23, 1): pauperes et divites Deus de uno limo fecit, et pauperes et divites una terra supportat" ${ }^{\prime 27}$.

En una palabra, si se apela al derecho divino, hay que determinar dónde está la Iglesia:

"Quid est Ecclesia? 'Ecclesia, dixit, cui praeerat Faustinus'. Sed non Ecclesiae praeerat Faustinus, sed parti praeerat. Columba autem Ecclesia est. Quid clamas? Non devoravimus villas, columba illas habeat: quaeratur quae sit columba, et ipsa habeat. Nam nostis, quia villae istae non sunt Augustini: et si non nostis, et putatis me gaudere in possesione villarum: Deus novit, ipse scit quid ego de illis villis sentiam, vel quid ibi sufferam: novit gemitus meos si mihi aliquid de columba impertire dignatus est" ${ }^{\prime 28}$.

En el desarrollo de la argumentación no se establece distinción alguna entre el Domini est terra y el columba illas habeat: son fórmulas equivalentes: de una se deduce la otra. San Agustín tiene mucho empeño en hacer constar que el dueño de las fincas eclesiásticas es Dios que rige a la columba, no Agustín, que es únicamente un administrador agobiado de preocupaciones. Al dar Gayo Seyo sus posesiones a Dios, las fincas adquirieron una personalidad semejante, por una parte, y por otra parte muy superior, a la personalidad que adquirían los colegios estatales con sus bienes. Si el Imperio era capaz de constituirlos en personae certae, es decir, fijas e intranferibles, mucho más lo es Dios, donatario de las fincas dadas a la Iglesia.

El defecto de la persona incerta característico de los collegia illicita y de sus bienes, queda superado en el cristianismo por el mero hecho de tratarse indistintamente de una renuncia, herencia o legado en favor de la religión, de Cristo, de los ángeles, de los santos o de los pobres, aun en el caso de que se deje algo nulla aede sacra adiecta. Digo indistintamente pues lo esencial es

${ }^{27}$ Ibid.

${ }^{28}$ Ibid. San Agustín procede en la administración de los bienes de la columba, como instrumento de la misma, no como dueño. En algunas de sus expresiones, san Agustín parece identificar a la columba con la Iglesia. Pero adviértase que en todo el tratado sexto, explica "quare Deus per columbae speciem ostendere voluerit Spiritum Sanctum" (n. 1, col.1425) En el desarrollo del tratado repite: "Columba, id est, Spiritus Sanctus in specie columbae" (n. 13, col. 1431) 
que salga de la órbita de la propiedad humana y entre en el dominio exclusivo de la transcendencia divina. Justiniano ${ }^{29}$ da normas concretas de prelación para determinar el templo o entidad para hacer efectiva la entrega de los bienes eclesiásticos dejados en forma indeterminada. Nada se deja al mero arbitrio humano, cuando se trata de bienes cuyo dueño único es Dios.

El pensamiento agustiniano es claro, pero carece de la formulación propia de las figuras jurídicas. Con el papa Gelasio I se acerca la disciplina eclesiástica a la fijación canónica perpetuada en la edad media. En las epístolas 33, 34 y 35 del año 495, el Papa, libre ya de las preocupaciones del poder imperial, prescribe definitivamente la disciplina canónica sobre los bienes eclesiásticos. En la carta ad Ioannem episcopum Sorarum permite Gelasio que una señora noble por nombre Magetia entierre a un familiar suyo en el oratorio privado, pero sin consagración del mismo y sin asistencia de fieles: "publica frequentatione et processione cessante" ${ }^{30}$. Magetia no quería renunciar a la propiedad del oratorio. El papa, sólo humanitatis causa, le permite esos actos privados de culto.

Al obispo Senecio le escribe sobre la fundación de una ecclesia levantada por Senilio en su finca, pero con una condición expresa;

"Es more convenit dedicari collata prius donatione sollemni quam ministris ecclesiae destinasse praefeti numeris testatur oblator; scriturus sine dubio, praeter procesionis aditum, qui ómnibus christianis debetur, nihil ibídem se proprii iuris habitorum" ${ }^{31}$.

Los términos son claros. La donación debe ser total eirrevocable, la renuncia absoluta y con destino a los ministros de la Iglesia en cuanto a ministros, no en cuanto a propietarios. El donatario es Dios. Las mismas instrucciones se dan a Herentencio obispo de Potenza (Italia) ${ }^{32}$. Las ordenaciones gelasianas determinan el carácter institucional de los bienes eclesiásticos dentro del derecho público de la Iglesia. La situación civilmente precaria de la Iglesia en los siglos anteriores había oscurecido el carácter público que les compete por su naturaleza a los bienes eclesiásticos por la perpetuidad de la Roca de Pedro y por la voluntad de los donantes. Es de importancia decisiva el carácter de derecho público de los bienes eclesiásticos, pues una de las características del derecho público es que sus administradores son meras causas instrumentales del legislador, que en último término es Dios.

${ }^{29}$ Tit 2

${ }^{30}$ Gelasio I, epist. 33, (edición de A. Thiel Epistolae Romanorum pontificum genuinae, Braunsberg 1867, 448)

\footnotetext{
${ }^{31}$ L. c. epist. 34 , p. 449

${ }^{32}$ L. c. p. 449
} 
A lo largo de la edad media no podían faltar tendencias egoístas mal avenidas con este carácter instrumental en la administración eclesiástica. El egoísmo de los señores territorrales hallaba en el ius fundi un pretexto para apropiarse las iglesias construídas en las fincas de su jurisdicción o propiedad. No es fácil determinar la extensión que alcanzó este abuso, descrito por el profesor Stutz de Bonn como institución germánica de carácter privado que se extendió por toda Europa ${ }^{33}$. El padre Bidagor y otros autores han impugnado el origen germánico de esta forma administrativa desprovista de carácter institucional $^{34}$. La lucha del institucionalismo eclesiástico y del funcionalismo germanista es muy significativa, pues en el institucionalismo destaca el carácter instrumental de la administración, mientras que el funcionalismo se caracteriza por la eficacia que el hombre busca como causa principal de las decisiones. El padre Bidagor prueba que en España no llegó a triunfar la teoría de las iglesias propias, que tropezaron muy pronto con la actitud de los padres del primer concilio de Braga (572):

"placuit ut si quis basilicam non pro devotione fidei sed pro quaestu cupiditatis aedificat, ut quidquid ibidem oblatione populi colligitur medium cum clericis dividat, eo quod basilicam in terra sua ipse condiderit, quod in aliquibus locis usque modo dicitur fieri. Hoc ergo de cetero observari debet, ut nullus episcoporum tam abominabili voto consentiat, ut basilicam quae non pro sanctorum patrocinio, sed magis sub tributaria conditione est tributa, audeat consecrare" ${ }^{\prime 35}$.

En el canon 5 del mismo Concilio se dan instruciones sobre la dotación:

"Hoc tantum unisquisque episcoporum meminerit, ut non prius dedicet ecclesiam aut basilicam, nisi antea dotem basilicae et obsequium ipsius per donationem chartulae confirmatum accipiat. Nam non levis est ista temeritas, si sine luminariis vel sine sustentatione eorum qui ibi servituri sunt, tamquam domus privata, ita consecretur ecclesia" 36 .

${ }^{33}$ Cfr. U. Stutz, Das Eigenrirchenrecht, als Element des mittelalterlich-germanischen Kirchenrechtes, Berlín, 1895

${ }^{34}$ R. Bidagor, "La Iglesia propia” en España. Estudio histórico canónico, Roma 1933 (Analecta Gregoriana 4).

${ }^{35}$ Canon 6; cfr. C. W. Barlow, Martini episcopi Bracarensis opera omnia, New Haven 1950, Yale University, 120; cfr. Bidagor, L.c., 65.

${ }^{36} \mathrm{Ibid}$ 
Con estas normas parece haberse realizado la reconstrucción de la diócesis gallegas organizadas conforme al Parochiale suevorum, en consonancia con la disciplina de Gelasio I. El concilio de Lérida del 524 ó 546 había establecido una distinción importante entre iglesias diocesanas y monásticas, que se ha prestado a diversas interpretaciones y pudo ser motivo de antagonismos.

"Ea vero quae in iure monasterii de facultatibus offeruntur in nullo diocesana lege ab episcopis contingatur. Si autem ex laicis quisquam, a se factam basilicam consecrari desiderat, nequamquam sub monasterii specie, ubí congregatio non colligitur, vel regula ab episcopo non constituitur, eam a diocesana lege audeat segregare" ${ }^{37}$.

La norma fundamental de la Iglesia es doble: por una parte no se deben admitir como donaciones hechas a Dios aquellas en que el dueño se queda con emolumentos temporales, Por otra parte, los bienes consagrados a Dios, deben conservar la índole primitiva de la donación. Si ésta se hizo con destinos monásticos, debe respetarse lo mismo que las iglesias diocesanas.

A este propósito se pueden citar las decisiones del canon décimo del segundo concilio de Sevilla (619):

"Decima actione poscentibus monasteriorum patribus, pari sententia statuimus, ut coenobia nuper condita in Baetica sicut et illa quae sunt antigua, immobili et inconcusa stabilitate permaneant solidata. Si quis autem (quod absit) nostrum vel nobis succedentium sacerdotum, quodlibet monasterium aut vi cupiditatis spoliandum, aut simulatione aliqua fradis convellendum, vel disolvendum, anathema effectus (...) Super hoc etiam universari Baeticae provinciae episcopi congregati, eundem sacri coetus eversorem a communione suspendant, convulsum monasterium cum rebus suis restaurent, ut quod impie unus subverterit, omnes pie reforment" 38 .

Más tarde el cuarto concilio de Toledo (633) urgía las mismas normas con la mayor severidad. La oblación del monje era una donación en todo semejante a la de los bienes eclesiásticos:

"Monachum aut paterna devotio aut propria professio facit; quidquid horum fuerit alligatum tenebit. Proinde hi ad mundum

\footnotetext{
${ }^{37}$ Cfr. R. Bidagor, 1. c. 54

${ }^{38}$ G. D. Mansi, Sacrorum Conciliorum Nova Amplissima Collectio, 10, 560
} 
reverti intercludimus aditum et omnem ad saeculum interdicimus regressum" 39 .

Por otra parte los obispos no tenían sobre el monasterio más jurisdicción que la puramente pastoral:

"Nunciatum est praesendi Concilio, quod Monachis episcopali imperio, servili opere mancipatus et iura monasteriorum contra constitutiones canonum, illicita praesumtione mancipentur; ita ut pene ex Coenobio possessio fiat, atque illustris portio Christi ad ignominiam servitutemque perviat. Quapropter monemus eos (...) Monachos ad conversationem sanctam praemonere. Abbates aliaque officia instituere atque extra regulam facta corrigere. Quod si aliquid in Monasterii rebus tentaverint, non deerit illis sententia excommunicationis" ${ }^{40}$.

Estos datos históricos aislados son nada en la inmensa historia de la propiedad colectiva, pero bastan para el fin que pretendemos de ilustrar históricamente el carácter eclesial de la pobreza colectiva, que lleva como rasgo distintivo la administración de la misma, a título de causa instrumental, no de causa principal.

No podemos seguir más la línea evolutiva de esta institución ${ }^{41}$. Estos rasgos fundamentales de la propiedad eclesiástica se pueden reducir generalizando, sin matizar demasiado la expresión, a estas cuatro:

$1^{\circ}$. Que los bienes renunciados se hacen del dominio transcendente exclusivo de Dios, sea cual fuere la forma en que se hacen: a Cristo, a los santos, etc.

$2^{\circ}$ - Que los bienes son para toda la Iglesia, o para los pobres.

$3^{\circ}$ - Que las donaciones una, vez hechas, son irreformables e intransferibles.

$4^{\circ}$ - Los administradores actúan institucionalmente, como causas instrumentales.

Pasemos ya a san Ignacio y a Suárez, dos testigos más del árbol frondoso de la pobreza colectiva en el cristianismo.

\footnotetext{
${ }^{39}$ Canon 49

${ }^{40}$ Canon 51

${ }^{41}$ Para encuadrar el pensamiento ignaciano en la historia de la pobreza, cfr. A. Delchard, "La genèse de la pauvreté ignatianne": Christus 6 (1959) 464-486
} 


\section{La concepción de los bienes eclesiásticos en San Ignacio y en Suárez}

La legislación de los concilios toledanos influyó en la estructura de la sociedad cristiana española medieval, que san Ignacio conoció perfectamente tanto en su casa señorial, como en la corte de Arévalo. Las dificultades, que más tarde se le presentaron y hubo de superar con ayuda de los grandes canonistas Guidiccione y Dal Pozzo, se referían directamente a la pobreza religiosa colectiva y no a la naturaleza de los bienes eclesiásticos. En las Constituciones se dan con extraordinario tacto las normas de la renuncia de los bienes, así para los candidatos de la Compañía ante ingressum como para los miembros de ella antes de la incorporación, siempre con el doble criterio de la absoluta libertad del renunciante y de la irrevocabilidad de la donación hecha a Dios. Antes del ingreso, el candidato puede disponer de sus bienes como cualquier propietario seglar, pero con la obligación derivada del dominio transcendental de Dios.

"7. G. Antes de entrar cada uno puede hacer de su hazienda lo que quisiere. Pero después de entrado, así de la eclesiástica, como de la seglar, debe disponer como a hombre que sigue vida espiritual conviene".

"7 (...) el disponer sea conforme a los consejos de Christo nuestro Señor; pero queda a la devoción de cada uno el emplear su hazienda o parte de ella, más en una obra pía que en otra, como Dios nuestro Señor le diere a entender que más conviene para su divino servicio" ${ }^{42}$.

$\mathrm{Ni}$ antes de entrar ni después de entrado tiene el candidato obligación alguna de dejar nada de sus bienes a la Compañía. Pero quien sintiera devoción de hacer renuncia en favor de ella, debe "remitir este juicio al que tiene cargo de toda ella, si deben aplicarse a un lugar más que a otro, de la misma provincia... teniendo miramiento a los Reyes, Príncipes y Señoríos, cómo no se les dé causa alguna de offensión y venga a la mayor edificación de todos". Antes de hacer renuncia, el renunciante es causa libre y principal para señalar el sujeto de la renuncia. Después de señalado el sujeto se atiene, como administrador instrumental, a las normas: una de ellas es que no le toca a él determinar disposiciones ulteriores sobre el uso de los bienes renunciados. En la Compañia ese cargo le toca al padre general, administrador universal de la Compañía.

${ }^{42}$ Ignacio de Loyola, Obras Completas, cit., 470 - 471: "Constituciones", parte 3a , capítulo 1 , números $7,7 \mathrm{G}$ y 9 [254, 256, 258] 
Si el candidato o el religioso no se resigna a estas normas y "en él vienen inclinación a un lugar más que a otro, lo que es imperfecto, aunque remitiéndose podrán informar al prepósito general, o a quien tuviera sus veces, si pareciere que alguna imperfección se debe tolerar".

Basten estos pasajes para probar la fidelidad de san Ignacio al principio general cristiano de la libertad absoluta del donante, que procede en su renuncia como causa principal de ella, no como instrumento de Dios. Un rasgo de fidelidad al principio de la irrevocabilidad de las donaciones sagradas es la pena de destitución del oficio que señala para el General, si incurriera en el pecado de "tomar las rentas de los colegios para sus gastos, o dar a quienquiera de fuera de la Compañía, o enajenar algunos bienes estables de Casas o Colegios"43. Como instrumentos de Dios, no puede adoptar esas decisiones de propietario insubordinado o de invasor del dominio divino. Esta severidad de san Ignacio recuerda la del segundo concilio de Sevilla y la del cuarto concilio de Toledo, antes citados. Al mismo criterio responde este otro pasaje:

"El transferir o deshacer Casas o Colegios ya fundados, o convertir en uso de la Compañía Profesa la renta de ellos, no lo podrá hacer el Prepósito General, como se dixo en la quarta parte" ${ }^{44}$.

Como atenuante de esta prohibición dice "alienar o deshacer del todo los Colegios o Casas ya erigidas de la Compañía, no lo pueda hacer sin la Congregación General”45. Lo que haga la Congregación general será dentro de los límites concedidos por la Sede apostólica.

San Ignacio se abstuvo de redactar las normas acerca de las atribuciones del general para determinación del destino de los bienes legados a la Compañía ${ }^{46}$. Una vez que el general es administrador universal de la orden, sería un contrasentido limitarle sus atribuciones. Pero tampoco pensó nunca que el instrumento de Dios pueda cambiar el destino de los bienes una vez incorporados a una obra pía, pues por sus propios principios espirituales sabía que estaban en poder de Dios inmediatamente, sin que al hombre le sea permitido decidir de cosas o bienes colocados bajo el gobierno da Dios ${ }^{47}$.

\footnotetext{
${ }^{43}$ Ignacio de Loyola, Obras completas, cit. 582: "Constituciones", 9, 4: 7 [774]

44 “Constituciones" 9, 3: 18 [763]

45 "Constituciones" 9, 3: 5 [743]

46 “Constituciones" 9, 3: 6 [744]

${ }^{47}$ Cfr. J. M. Aicardo, Comentario a las Constituciones de la Compañia de Jesús, Madrid 1932 , v. 6, 378 ss, donde se recogen diversos datos sobre la dificultad experimentada por san Ignacio al principio, para determinar él la aplicación de los bienes destinados a la Compañía.
} 
San Ignacio adoptó esta posición sin intervenir en la discusión que los grandes canonistas de su siglo, comenzando por Torquemada y Cayetano para terminar en Navarro, agitaban sobre el propietario de los bienes eclesiásticos. Suárez se ocupó de la controversia matizando las opiniones controvertidas. Torquemada y Cayetano habían defendido la postura, que Suárez llama receptior in hoc tempore, "quae docet huiusmodi bona esse sub dominio particulari Ecclesiae vel universalis, vel particularis respective ad ipsa bona, iuxta intentionem eorum, qui talia bona ecclesiis donarunt" ${ }^{\text {"48 }}$. Esta observación de Suárez, más que su propia opinión, refleja la tendencia histórica a admitir en el derecho congregaciones religiosas centralizadoras de la propiedad, conforme a los últimos sistemas de la clasificación arriba copiada del padre A. Gutiérrez.

Navarro, en cambio, "docet omnia bona utriusque generis id est sacra, vel ecclesiastica immediate esse sub dominio Dei et Christi domini, non per metaphoram, sed per omnimodam proprietatem, ita ut nullus homo vel hominum congregatio habeat proprium dominium, sed tantum dispensationem cum maiori vel minori plenitudine potestatis, quam sententiam dicit esse communem consensum omnium catholicorum doctorum" 49 .

Suárez piensa que la discusión "fortasse est quaestio de nomine"

La sentencia de Navarro es "satis pia et probabilis" por cuatro razones, cuya fuerza probativa no se pone en discusión.

$1^{\text {a }}$ Porque estos bienes se llaman bona Dei, patrimonium Christi en las fuentes civiles y canónicas. 2a "Quia si aliquis homo esset dominus horum bonorum maxime esset Summus Pontifex apud quem est suprema potestas illa dispensandi (...) sed Summus Pontifex non habet proprium dominium etiam eorum, quae peculiariter sunt Ecclesiae Romanae... ex conc. romano". $3^{\text {a }}$ Por autoridad del Papa Símaco: "non enim potest suo arbitrio haec

Más tarde, se avino a hacer tales aplicaciones, lo mismo que san Francisco de Borja. La actitud de san Ignacio recuerda la de los apóstoles en no querer mezclarse para nada en tomar tales decisiones. Una vez hecha la aplicación no hay indicio alguno para sospechar que san Ignacio se creyera autorizado a hacer cambios ni transferencias. Es significativa la razón última con la que se determina a no aceptar las ventas a que había renunciado. "17. Propio es de Dios nuestro Señor ser inmutable y del enemigo mutable y variable", Ignacio de Loyola Obras Completas, cit., 299: "Deliberación sobre la pobreza" (1544), n. 15. Este principio válido siempre para el criterio de la Iglesia en toda clase de instituciones, lo es particularmente en el tema de la propiedad y de la pobreza, y san Ignacio lo pone como fundamento de la Compañía en el primero de los votos simples de los profesos.

\footnotetext{
${ }^{48}$ F. Suárez, Conselhos e pareceres II/II 285

${ }^{49} \mathrm{Id}, 284$

${ }^{50} \mathrm{Id}, 285$
} 
bona expendere, seu alienare, sed tantum ut fidelis et prudens dispensator: ergo nec Ecclesia ipsa universalis". $4^{\circ}$ "Neque est inconveniens quod aliqua bona humana et temporalia sint extra dominium mortalium, quia fideles altiori mente quam humana, nempe per fidem operando illa Christo domino donare seu reddere potuerunt et voluerunt: et ipse quamvis per ministros suos illa acceptet inmediate, fit proprius illorum dominus" ${ }^{51}$.

Todo esto es verdad. Pero Suárez puntualiza las expresiones de Navarro en que se excede al excluir todo dominio humano de los bienes eclesiásticos. Comenzando por los objetos sagrados, aunque por la consagración o bendición se hallan extra humanum commercium, como los templos y vasos sagrados, y pertenecen peculiari iure ad Christum Dominum, "hoc tamen non obstat quominus sint sub dominio Ecclesiae vel communitatis ecclesiasticorum (...) quia nec Ecclesia aut communitates ecclesiasticorum eo ipso quod res istae consecratae sunt ex natura rei fiunt incapaces dominii circa materiam rei consecratae" $" 52$.

En los bienes inmuebles, como fincas y casas o derechos fructíferos como censos o réditos, es evidente que están sub humano dominio modo dicto, "quia sunt acquisita Ecclesiae vel communitati ecclesiasticorum iusto titulo, ut supponimus, et neque "Ecclesia neque ecclesiasticae personae secundum se et absolute loquendo sunt incapaces dominii, ut fide certum est, et inferius dicetur. Eadem ratio est de fructibus ecclesiasticis necessariis ad sustentationem ministrorum Ecclesiae, vel in pauperes et alia pia opera expensis, quia cum sint donata Deo et ordinata ad eius cultum et obsequium, sunt peculiari iure modo explicato sub dominio Dei, ut significavit conc. Trident. sess. 25, cap. $1^{\mathrm{o}}$ de reformatione prohibens episcopis ne res ecclesiasticas, quae, inquit, Dei sunt, consanguineis donent" ${ }^{53}$. De aquí las normas prácticas:

"ideoque priora bona (=res sacrae) dici solent exempta ad humano commercio et usu; haec vero posteriora (=immobilia et mobilia) esse possunt in humano commercio, et ad ordinarios usus applicari, dummodo debito modo et cum pietate fiat (...). Quod si bona sunt immobilia vel pretiosa, peculiare habent privilegium, ut alienari non possint, nisi modo et ratione iure canonico praescriptis" ${ }^{54}$.

\footnotetext{
${ }^{51}$ Ibid.

${ }^{52}$ Id., 286

${ }^{53}$ Id., $287 \mathrm{~s}$

${ }^{54}$ Id., 289
} 
Adviértase la afirmación de que las personas eclesiásticas no son incapaces de dominio secundum se et absolute loquendo. Es una precisión necesaria. Las personas eclesiásticas, que per se no son incapaces de dominio. Hay personas eclesiásticas, que per accidens, por razones especiales, son incapaces de tal dominio, como lo veremos al tratar de la pobreza colectiva. De la pobreza individual no hay duda de ello. La incapacidad secundum se la excluye Suárez en el tratado De iustitia et iure recién publicado por Giers:

"Non omnes subditi pape, imperatori vel cuicumque regi supremo sunt incapaces dominii. Nec illi principes habent proprium et particulare dominiun rectum bonorum omnium suorum subditorum (...) Primo: quia contraria sententia nullo nititur fundamento et parat viam omni iniquitati et iniustitiae (...) Et papa, licet habeat iurisdictionem ratione spiritualis protestatis, non tamen dominium nisi fortasse in propriis reditibus... ${ }^{55}$.

Resumiendo. Los bienes eclesiásticos todos pertenencen de algún modo especial a Dios. Todos, inmediata o mediatamente, son eclesiales, es decir para la Iglesia. Las comunidades eclesiásticas y religiosas per se no son incapaces de algún derecho de propiedad, más o menos limitado por el derecho canónico, respecto de tales bienes. Una limitación es siempre la voluntad del donante. Otra limitación es la capacidad de las mismas comunidades, que pueden estar excluídas a veces por el derecho, a veces por el voto especial de la pobreza colectiva.

Suárez hubo de intervenir en el asunto de la fundación real del Colegio de Salamanca. Ya en 1601 la reina doña Margarita prometió 200.000 ducados para erigir y dotar el colegio con suficiente capital para mantener 300 personas. En 1611, antes de morir, redactó un codicilo para hacer efectivas aquellas promesas, aunque sin las formalidades todas exigidas por las leyes de Castilla para los legados testamentarios. Se conservan dos respuestas en los Conselhos e pareceres de Suárez sobre este asunto, aunque los editores duden de la autenticidad suareciana de uno de ellos. Se trata de una suma que se debía de obtener del oro aportado en las galeras reales. Suárez mantiene la opinión de que aquella suma pertenecía a la obra pía prometida, aún antes de que entrara en la hacienda real, sólo por la promesa hecha a la obra pía, es decir al patrimonio sagrado:

"Se responde que sus altezas ningún derecho tienen a estos duzentos mil ducados. Lo primero, porque la reina N. S. nunqua tuvo dominio dellos: porque se consideran antes de

\footnotetext{
${ }^{55}$ J. Giers, Die Gerechtigkeitslehre des jungen Suárez,
} 
consignarlos en la hazienza real a la obra pía del colegio, o después de consignarlos y aplicarlos. Si antes, se quedan en poder del rey N.S. como consta de las palabras de la facultad (dada por el mismo Rey). Si después, ya el dominio pertenece a la obra pía" ${ }^{\prime 6}$.

En la colisión con las leyes de Castilla y las cargas de la Corona real, Suárez hace ver que sobre las unas y las otras están las exigencias de la ley natural en derechos aquiridos por dios en las donaciones voluntarias.

Por el mismo tiempo hubo de trasladarse Suárez a Oporto por encargo del colegio de Coimbra y del obispo de Oporto para solucionar los conflictos jurídicos existentes entre el colegio de Coimbra y el suprimido monasterio de Pedrozo, cuyos bienes habían sido transferidos a dicho colegio en tiempo de san Pío V. Gregorio XIII había resuelto varias dudas el uno de septiembre de 1584, pero volvieron a a surgir otras dificultades en 1605 y 1607.

Suárez se basa en que Gregorio XIII “distingue en aquella iglesia conventual, otra de Iglezia Parrochial, y declara que por la dicha unión y encorporación del dicho monasterio perdió toda la razón de Iglesia conventual y por consiguiente extinguieron todas las obligaciones de cirimonias, solemnidades e offizios divinos, que en la tal Iglezia en quanto era conventual avía, y sólo se conserva en razón de Iglezia Parrochial, por consiguiente declara en ella se conservan las obligaciones de Iglezia Parrochial, tanto en la cura de almas, quanto en los offizios divinos" $" 57$.

La solución era idéntica a la aplicada para la incorporación de los monasterios extinguidos en la diócesis de Braga, S. Fins y S. Joae al ser anexionados al colegio de Coimbra. Suárez termina su dictamen diciendo:

"Mas pareceme a min que se podía encomendar al Vicario en la Visitación, que tuviese cuidado todos los años algún mes antes de la quaresma, de pedir al P. Rector del Colegio de la Compañía, que provea aquella Iglezia de predicador y compañero que ensiñe la doctrina como lo hace en otros monasterios unidos aquel colegio o por charidad o gratitud, sin otra obligación y sin hacer costa ninguna a los pueblos e vicarios (...) Sub censura en el Puerto a 16 de octubre de $1611^{\prime 58}$.

${ }^{56}$ F. Suárez, Conselhos e pareceres v.1, 390; cfr. ibid. 317-326, para la dudosa autenticidad, aunque concorde con la citada.

${ }^{57}$ Id., 331

${ }^{58} \mathrm{Id} ., 336$ 
El año 1608 intervino Suárez en las discusiones suscitadas durante varios decenidos en la Compañía por la interpretación de la congregación general tercera a la cláusula ignaciana arriba citada para los casos en que el renunciante quiere dejar sus bienes a la Compañía. Las constituciones dicen que la renuncia sea a favor de obras de la misma provincia. En la congregación tercera se dio una interpretación favorable a las provincias de Toledo y de la Bética, de donde procedían muchos candidatos estudiantes de Salamanca que ingresaban en Castilla. Esta provincia, que debía sufragar los gastos de las carreras de estos candidatos, se veía imposibilitada para sostener a sus estudiantes, si éstos no podían renunciar sus bienes a favor de Salamanca. Se conservan dos estudios dirigidos a la congregación de 1608, uno de ellos anónimo y el otro de Suárez, impugnando como poco equitativa la interpretación de la congregación tercera.

"Son cuatro las razones en que Suárez apoya su postura. Las dos primeras son interpretación del texto ignaciano. La tercera se funda en la equidad, pues nadie milita a sus expensas. Éste es el fundamento del derecho civil y canónico, por el que el monasterio es heredero de los que en él entran. La cuarta razón son los absurdos de la interpretación contraria, pues si se priva a las academias de los fondos de sus religiosos, estos no podrán ser recibidos en esa provincia, y perderán la vocación al regresar a sus casas, por los obstáculos de los parientes a su ingreso. Ésta parece haber sido la razón por la que Suárez entró en Castilla y no en la Bética. En suma, la opinión de Suárez parece fundarse en la inclinación y necesidades de los mismos que entran en religión ${ }^{59}$.

Las ideas de san Ignacio y Suárez, elementales en el derecho público cristiano, están inspiradas en la fidelidad más acendrada al concepto tradicional de la propiedad eclesiástica colectiva. Por ser de institución de derecho público, está esencialmente ordenada al bien común de la Iglesia, no al bien particular. Es de función esencialmente social y más aún transcendental, pues se orienta al servicio divino, aunque no por medios de elección individual, sino conforme a las normas solemnes de la Iglesia. Este rasgo de transcendentalidad es una nota exclusiva del derecho de la Iglesia, que el derecho civil no siempre tiene en cuenta. Por eso el derecho público de la propiedad eclesiástica no coincide del todo con la materia análoga civil. Suárez y otros autores desarrollan extensamente esta diferencia entre los bienes profanos y los bienes eclesiásticos.

\footnotetext{
${ }^{59}$ Manuscrito inédito del Archivo de Loyola, s. $1^{\mathrm{a}}$, ser. $1^{\mathrm{a}}, \mathrm{n}^{\mathrm{o}} 21$.
} 
Bastaría lo dicho para el carácter público de la propiedad colectiva eclesiástica, pero además la propiedad eclesiástica está regulada lo mismo para su adquisición que para la administración por normas públicas, que excluyen todo negocio arbitrario y clandestino. La Iglesia tienen derecho a saber cómo se administran los bienes del patrimonio de Cristo. Por racional y ventajoso que en determinadas circunstancias sería comercialmente un negocio, más aún por ventajoso que parezca aun para la gloria de Dios, la Iglesia tiene normas, como el respeto a la voluntad de los donantes y la irrevocabilidad de los donativos hechos a Dios, que no se pueden soslayar lícitamente. Sólo en caso de necesidad son posibles las supresiones de corporaciones, de obras pías o fundaciones o sus traslados totales o parciales, como hemos visto en los casos estudiados en Suárez.

Dentro de la fidelidad abosuta a la doctrina tradicional que ha pasado hasta el derecho eclesiástico actual ${ }^{60}$. Los principios ignacianos y la doctrina de Suárez permiten establecer una gradación jerárquica entre las clases de dominio y de propiedad, que Suárez desarrolló dogmáticamente al atribuir a Dios el dominio transcendente, a Cristo en cuanto hombre el dominium excellens universal, y al hombre el dominio temporal ${ }^{61}$, que en el cristiano debe ser sólo administrativo, como instrumento divino o causa principal. Sobre estos principios se levanta la doctrina económicosocial, que "es una parte integrante de la concepción cristiana de la vida" ${ }^{62}$ y por lo tanto, obligatoria cuando el evangelio o la jerarquía se pronuncia en la materia.

Como indicamos al principio, las normas del evangelio tienden a la edificación de la Iglesia, pero esa edificación puede obtenerse por actos directamente per se eclesiales, o por actividades honestas indirecta y ocasionalmente eclesiales. En las primeras, el hombre es sólo causa instrumental, cada uno dentro de su esfera y grado evitando el "plus sapere quam oportet sapere... unicuique sicut Deus divisit mensuram fidei" (Rom 12,3). Todos los ejercicios ignacianos tienden a ofrecerse al Señor para hacerse el hombre mero instrumento divino eclesial, como un ser puramente funcional de la institución divina que es la Iglesia. En cuanto a Suárez, como es sabido, uno de los principales elementos de su sistema doctrinal es la capacidad de todo ser creado para ser elevado como instrumento a una acción externa, que no repugne, incluso sobrenatural. Los bienes materiales son, por tanto, extrínsecamente elevables por Dios a la edificación de la Iglesia.

\footnotetext{
${ }^{60}$ Código de derecho canónico (1917) canon $\mathrm{n}^{\circ} 1499$

${ }^{61}$ F. Suárez, De incarnatione. Disputatio 58, s. 2; 18, 466-469

${ }^{62}$ Juan XXIII, Encíclica. Mater et Magistra AAS (1961) 453s
} 
Pero tanto san Ignacio como Suárez suponen explícitamente que Dios puede contentarse con la sola oblación, dejando a las causas segundas obrar como causas principales. Así, los bienes temporales renunciados en favor de una congregación religiosa, sin devenir instrumentos divinos, pueden realizar una acción importantísima en el crecimiento y conservación de la Iglesia. Pero son dos caminos diversos. San Ignacio y Suárez aspiran a la total instrumentalidad divina, reconociendo que en muchos casos puede quedar la propiedad de los bienes sagrados en manos de hombres religiosos y santos

\section{La pobreza de la Compañía}

Dios, artífice supremo de su gloria, toma a veces por Sí mismo los instrumentos de su glorificación. Así los miembros del cuerpo místico son instrumentos del Espíritu Santo. Otras veces Dios forma artífices creados que procuren la gloria divina con sus talentos recibidos. ¿Qué carácter le corresponde a la Compañía en sus actividades por la gloria divina? Es mero instrumento eclesial, como los apóstoles y la jerarquía, o es un artífice que procede como causa principal mediante las casas y bienes de su propiedad? A esta pregunta debemos contestar examinando las bulas funcionales del Instituto.

Pablo III había señalado, con la ayuda del gran canonista Guidiccione conforme a los deseos de san Ignacio y sus compañeros, las líneas fundamentales de la pobreza colectiva de la Compañía en 1540. Diez años más tarde, confirmó y aclaró Julio III las mismas bases asesorado por el canonista Dal Pozzo. Es instructivo cotejar ambas bulas fundamentales.

\section{Regimini militantis Ecclesiae}

27 septiembre 1540

"Non solum privatim, sed neque etiam communiter possint pro Societatis sustentatione aut usu, ad bona aliqua stabilia, aut ad proventus seu introitus aliquos, ius aliquod civile acquirere; sed sint contenti usum tantum rerum sibi donatarum, ad necessaria sibi comparanda, recipere. Possint tamen habere in

\section{Exposcit debitum}

21 julio 1550

"Non solum privatim, sed neque etiam communiter possint Professi vel ulla eorum domus aut Ecclesia ad aliquos proventus, redditus, possessiones, sed nec ad ulla bona stabilia, (praeter ea quae opportuna erunt ad usum proprium et habitationem) retinenda, ius aliquod civile 
Universitatibus Collegium seu Collegia, habentia redditus, census seu possessiones, usibus et necessariis Studentium applicandas; retenta penes Praepositum et Societatem omnimoda gubernatione, seu superintendentia super dicta Collegia et praedictos Studentes, quoad Gubernatoris seu Gubernatorum ac Studentium electionem (...); sic tamen ut neque Studentes dictis bonis abuti, neque Societas in propios usus convertere possit, sed Studentium necessitati subvenire" $"$. acquirere, rebus sibi ex charitate donatis ad necessarium vitae usum contenti, (...) possit Professa Societas ad studiorum commoditatem, Scholarium habere Collegia, ubicumque ad ea construenda et dotanda e devotione aliqui movebuntur; quae simul atque constructa et dotata fuerint (non tamen ex bonis, quorum collatio ad Sedem Apostolicam pertinet), ex nunc Auctoritate Apostolica erigi supplicamus, seu pro erectis haberi; quae Collegia possint habere redditus, census seu possessiones, usibus et necessitatibus studentium applicandas, retenta penes Praepositum vel Societatem omnimoda gubernatione seu superintendentia super dicta Collegia et praedictos Studentes, quoad Rectorum sen gubernatorem ac Studentium electionem (...); ut neque Studentes dictis bonis abuti, neque Societas Professa in proprios usus convertere possit sed Studentium necessitati subvenire" ${ }^{64}$

En estas dos bulas fundamentales están trazados los rasgos de la pobreza individual y sobre todo de la pobreza colectiva de la Compañía. La bula Ascendente Domino de Gregorio XIII no se refiere a este aspecto de la Compañía, como tampoco la bula Exponi nobis encaminada a facilitar al General algunos negocios jurídicos, pero siempre ad evidentem utilitatem domus vel collegii.

\footnotetext{
${ }^{63}$ Monumenta ignatiana, Constitutiones Societatis Iesu, 3-1 Roma 1934, 29-30 (MHSI 63)

${ }^{64}$ Ibid, 379-380
} 
Pablo III y Julio III distinguen con claridad entre la Compañia, incapaz de poseer bienes estables, ni rentas, etc., pero capaz de tener colegios o casas de formación de estudiantes, los cuales colegios pueden poseer bienes muebles e inmuebles con rentas, y a nombre de los cuales puede el General o sus delegados firmar ventas y contratos en calidad de administrador de ellos, nunca para provecho propio o de la Compañía profesa. La Compañía es pobre privada y colectivamente.

Con esto es claro que la palabra habere se emplea en diversos sentidos cuando se refiere a la Compañía y a los colegios. Aquélla puede tener la superintendencia y el gobierno, como lo podían tener los obispos en algún sentido respecto de los monasterios, según los concilios de Sevilla y de Toledo arriba citados; pero no pueden tener la propiedad de los bienes materiales. Los colegios, en cambio, no tienen la autonomía gubernativa respecto de la Compañia, pero tienen el derecho de propiedad de que aquélla es incapaz. Dentro de la legislación y figuras canónicas tradicionales de la Iglesia las bulas de Pablo III y Julio III no ofrecen dificultad en este punto. Cabe una pequeña ambigüedad en el uso de la palabra colegio, que se puede entender como persona jurídica tanto colegial como no colegial; es decir en el caso primero como entidad puramente jurídica, a saber cómo el cabildo catedralicio, y en el segundo como un conjunto de bienes raíces fundamentales de una fundación u obra pía. Lo probable es que en las bulas tengan un sentido cumulativo: el colegio es ambas cosas, aunque en realidad se puedan separar, como ocurría en los monasterios extinguidos de Pedrozo, San Fins y San João estudiados, incorporados por los papas al colegio de Coimbra. En el diccionario de Covarrubias (1611) se le asignan ambos sentidos, el jurídico de congregación y compañia y el de "casas instituídas para criarse en ellas hombres bien nacidos".

Para la claridad de estos documentos constitutivos de la Compañia, solicitados y aceptados por san Ignacio, podría parecer superfluo discutir sobre la mente del fundador de la Compañía en cuanto fundador. El que personalmente tuviera algunos conceptos más o menos oscuros sobre la pobreza colectiva tendría un interés puramente anecdótico sin consecuencias jurídicas. A nuestro juicio, el pensamiento está bien claro, y aunque no tenga fuerza de ley, ayuda para comprender el derecho básico de la Compañia que está en sus bulas pontificias fundacionales. Ni el general ni las congregaciones generales pueden mudar lo más mínimo los rasgos institucionales de la orden. Recientemente se ha querido ver un punto discordante de gran transcendencia entre las bulas de Pablo III y Julio III, en la frase de la última: "sed neque ulla bona stabilia, praeter ea, quae opportuna erunt ad usum proprium et habitationem". Apoyado en esta frase ha deducido el padre Ignacio Gordon, que "cierto, es sentencia probable que los Profesos, en cuanto constituyen la Compañía Profesa, tienen 
dominio en común de todos los bienes estables, "quae opportuna erunt (...)". En este caso la bula de Julio III no sería una confirmación sino una radical modificación (acaso destrucción) de la Compañía aprobada por Pablo III ${ }^{65}$.

Gramaticalmente el praeter ea, puede significar praeter eas res, praeter ea bona stabilia. Si sólo se atiende a la yuxtaposición stabilia, praeter ea, se diría que praeter ea se refiere a bona stabilia. Pero al interpretar no sólo se tiene en cuenta la proximidad de los términos sino también la significación lógica de la frase. En las Constituciones (6, 2:5), se dice: "No solamente pero ni possesiones tengan las Casas o Iglesias, fuera de lo que para su habitación y uso...". El fuera de lo que es igual al praeter ea quae. En la otra interpretación, la Compañía tendría derecho a poseer todos los bienes estables oportunos, como cualquier persona o entidad seglar, que nunca retiene bienes estables o inestables que no crea oportunos. En el primer caso, en cambio, la oportunidad se refiere a retener las cosas necesarias en la vida conforme a la conclusión de la frase: "rebus sibi ex caritate donatis ad necessarium vitae usum contenti". Esta segunda interpretación concuerda con el resto de la bula. La primera es incompatible con el contexto, y destructiva de toda pobreza evangélica y no evangélica. Sirviéndonos de una expresión moderna, podría decirse que la bula de Julio III permite expresamente un régimen de subsistencia, pero no un régimen de producción, a la Compañía y sus casas profesas.

\section{La mente de San Ignacio}

Las Constituciones de san Ignacio son posteriores a la fundación de la Compañía. San Ignacio las escribió para "que ayuden para mejor proceder, conforme a nuestro Instituto, en la vía comenzada del divino servicio". Son, por lo tanto, Constituciones que se basan en el instituto ya fundado canónicamente, e interpretan y desarrollan, sin salir de las bulas, la legislación de la Compañía conforme al espíritu con que fue fundada. Separar la espiritualidad contenida en las Constituciones de las bases jurídicas de las bulas, sería algo así como separar el espíritu evangélico y las disposiciones eclesiásticas, como dos elementos no sólo distintos sino perfectamente separables.

A pesar de estas consideraciones, últimamente se han formulado objeciones contra la cohesión del pensamiento ignaciano, partiendo de varios pasajes de sus Constituciones ${ }^{66}$. Las principales son las siguientes.

${ }^{65}$ Cfr. I Gordon, "El Sujeto de dominio de los Colegios de la Compañía de Jesús en la controversia alemana sobre la restitución de los Monaterios": ATG 16 (1953) 49.

${ }^{66}$ El padre Gordon refuta a Laymann, cuando dice que la Compañía, por ser un corpus 
"Luego en siendo entregado algún Colegio a la Compañía...". La traducción latina tiene in possessionem venire. La traducción es ambigüa. Pueden entregarse sólo derechos jurisdicionales sin entrega de la propiedad.

"La posesión de los Colegios con lo temporal que a ello toca, tomará la Compañía, poniendo Rector (...); el cual tomará cargo de conservar y administrar las cosas temporales (...); el cual no pudiendo convertir en uso suyo ni de algunos parientes suyos, ni de la Compañía Profesa las cosas temporales de los Colegios..." $"$.

Respecto al in possessionem venire, la dificultad carece de base. En un grabado que tenemos delante, la leyenda dice así: "El 23 de noviembre de 1958 Juan XXIII, como Obispo de Roma, tomó posesión de su Catedral, San Juan de Letrán". En la foto se ve al Papa que, siguiendo un rito antiquísimo, toma posesión simbólica de la basílica poniendo sus manos sobre las llaves de la misma "que le son presentadas por el cardenal-arcipreste Luis Masella"68.

La claúsula copiada de las Constituciones tiene el mismo sentido que esta leyenda. El Papa toma posesión poniendo las manos sobre las llaves (=símbolo de jurisdicción y gobierno) y la Compañía lo hace poniendo rector, que administre y gobierne. Sería grotesco pensar que una toma de posesión de una catedral, de un colegio, de un gobierno civil, lleva consigo la adquisición del derecho de propiedad sobre los bienes muebles o inmuebles de aquello cuya posesión toma.

En el pasaje ignaciano se distingue cuidadosamente el colegio (entendido como fundación, no como comunidad o persona colegial) y lo temporal que toca al colegio. En la declaración de la letra $\mathrm{C}$ añade san Ignacio: "Y del mesmo Prepósito o a quien él cometiere el recibir lo que se diese a los tales Colegios para la sustentación y augmento dellos en las cosas temporales".

con sus escolares, es propietaria de los colegios fundados por ella. Refuta también a Mangioni y Crusius que niegan tal propiedad de la Compañía, y sigue la interpretacion de Veihelin, patrocinada por Hoffaeus y Nicasio, según los cuales la propiedad de los colegios pertenece a la Compañía, conforme a los párrafos ignacianos citados en el texto. El padre Gordon supone que san Ignacio tiene pasajes favorables para las dos tesis, posición que sería modificativa de la Compañía. A nuestro juicio, los intérpretes del siglo XVII no tuvieron en cuenta la heterogeneidad de la Compañía de que habla Suárez. En ella hay personas colegiales, todas incapaces de propiedad, y personas no colegiales (pías fundaciones, colegios) capaces de propiedad.

67 “Constituciones" 4, $1: 4$ y $4,2: 5$

${ }^{68}$ A. Galter, El nuevo Papa Juan XXIII, Madrid 1958, 200 
Los colegios son, por lo tanto, los que reciben y aumentan como personas morales, verdaderos sujetos de derechos y obligaciones, aunque gobernados y administrados por la Compañía. Todas las frases están formuladas aquí con la precisión de un canonista profesional, que está describiendo el régimen de una pía fundación, que la Compañía no funda, ni dota, ni erige, sino que recibe plenamente constituida para administrarla y gobernarla.

Lo mismo se diga del pasaje primero del mismo capítulo segundo: "Acerca del admitir los Colegios que se ofrecen libremente a la Compañía, para que en todo disponga dellos conforme a sus Constituciones...". La persona moral de un Colegio se admite como se admite la persona física de un candidato, sin que en ninguno de los casos adquiera la Compañía derecho de propiedad sobre la persona que admite ${ }^{69}$.

La misma precisión se advierte poco antes ("Constituciones" 4, 1:4): "Luego en siendo entregado algún Colegio a la Compañía, el Prepósito General avise a todas partes della universalmente...". No se dice que se entrega a la Compañía los bienes con los que pueda fundar un Colegio, sino el Colegio mismo al cual pertenecen los bienes necesarios para su sustento. Lo que se entrega es una persona moral. Lo mismo que cuando un candidato se entrega a la Compañía. En ninguno de los dos casos se entregan a ella los bienes materiales poseídos en propiedad por las personas que se le entregan. El caso es análogo, con la diferencia de que el Colegio no hará ni puede hacer renuncia de sus bienes materiales, mientras que el candidato, antes de hacer la profesión, habrá de renunciar a sus bienes en favor de los pobres, entre los cuales se podrán considerar obras o colegios de la Compañía, pero nunca la misma Compañía.

${ }^{69}$ Sobre el concepto de la personal moral, cfr. "Persona e institución": Estudios de Deusto 7 (1959) 41, donde recogemos Ia definición de G. Michiels, De personalitate morali, Roma 1953 (Analecta Gregoriana 69), 4 "Persona moralis, tum collegialis tum non collegialis, a legislatore concipitur tamquam ens realiter existens essentialiter constans ex pluralite quadam, personarum physicarrum scilicet vel rerum, ad determinatum finem ecclesiasticum, religiosum vel charitativum Ecclesiae proprium permanenter essequendum provisa, cui qua subiecto (reali, metaphysico, iuridico, ideali, ficto, iuxta diversas theorias a diversis Auctoribus propugnatas) per se stanti et in se uni, unico et indivisibili, an elementis realibus concretis (personis physicis vel rebus) quae eius substratum materiale actualiter constituunt formaliter distincto, ab auctoritate ecclesiastica publica agnita est determinata summa iurium et obligationum in Ecclesia, cum capacitate iuridica omni subiecto iurium propria". Estas notas se hallan especialmente en el Código de derecho canónico, cánones 87 y 99, y son resultado de la tradición canónica constante de la Iglesia. Suárez supone la realidad de estos entes jurídicos como lo probamos en "La realidad jurídico moral. Esquema Histórico": Anales de la Cátedra Francisco Suárez 1 (1967) 3-29. 
Tales son los pasajes aducidos como loca graviora por Fine ${ }^{70}$. La dificultad surge, en efecto, si se considera a los colegios como meros conjuntos de bienes materiales cotizables en dinero; pero se disipa totalmente en cuanto se los considera como personas morales. Los esquemas "Para fundar colegios" de 1541- 1544 confirman esta interpretación, como se puede ver por los párrafos siguientes, más significativos:

\section{1}

2. Primeramente, si Dios nuestro señor, para su propio honor, servitio y alabança nos diese algunos benefactores para fundar algún collegio o algunos, el fundador de tal collegio, dando orden probeyese que el dicho collegio tubiese dominio sobre sus rrentas y possessiones para nutrir estudiantes, de modo que del collegio fuese rrecibir dineros, possessiones y rrentas, y hazer pleytos, quando fuese necesario para la conservatión de lo que le perteneçe.

3. Que el fundador ponga que la Compañía no pueda in eternum dar ni recibir ninguna rrenta $o$ otra cosa que al tal collegio pertenesce, para convertir en propios vsos ny en alienos, ny de vna manera ni de otra.

\section{4}

1. Primeramente, Dios nuestro Señor por la su infinita y summa bondad ordenando y elegiendo para su propio servicio, alabança y gloria algunas buenas personas, que fuesen fieles y dignos instrumentos de la su divina magestad para fundar algún collegio, collegios o casas "para escolares pobres", el fundador de tal collegio o collegios deue seer en dar orden y proueer que "en el tal" collegio "se ponga" un primario o rector, "el cual" tenga todo dominio sobre sus rentas y possessiones para nutrir escolares de modo que del Collegio sea reçebir dineros, possessiones y rentas, y "defender y procurar su derecho en juyzio", quando fuese neçesario para la conservaçión y defensión de los que le pertenece.

${ }^{70}$ Ius regulare quo regitur societas Jesu, p. 467. El padre Fine (p. 465), basado en estos pasajes y en su interpretación a los comentarios de Nadal, cree que la Compañía toda, especialmente la profesa, es el sujeto de dominio de los bienes de sus casas. Suárez, según Fine, defiende que las casas son poseídas por sus comunidades. No creemos exacta ninguna de estas dos interpretaciones, como se desprende del examen de los pasajes. 
4. El fundador ponga a la Compañía por superintendente cerca el tal collegio para quitar y poner todos officiales y rregidores $\mathrm{y}$ otras personas (...).

27. ... si Dios nuestro Señor por algún su especial instrumento nos diere alguna casa, es nuestra intención que la casa pueda tener rrenta para ella misma, es a saber, para la sacristía, adornamiento de la casa, botica, librería, fuego y ajuar della, como en vn hospital bien ordenado sería aver todo lo necessario en él para los viandantes

29. Sy algún fundador fundare alguna casa assi rrentada (...) sy alguno pidiere la casa o la renta della y quisiere hazer pleyto, que la ciudad o la persona principal le rresponda, y si tiene derecho lo defienda, si le pareciere. Si la ciudad o algunos quisieren echar fuera de la casa y de la rrenta della a la Compañía; que la Compañía tenga paciencia, como no tenga derecho a ella.
2. Asimismo el fundador ponga que la Compañía no pueda in eternum dar ni recebir renta "alguna, ni otra cosa estábile ni mobile" que al tal collegio "pertenezca", para conuertir en propios husos ni en alienos, ni de una manera ni de otra.

3. El fundador ponga a la Compañía por superintendente çerca el tal collegio, para quitar y poner todos rectores, preceptores, escolares, officiales y todas otras personas $(\ldots)^{71}$

Con razón advierten los editores que el número 27 refleja la mente de san Ignacio y sus compañeros el año 1541, al recibir la bula Regimini militantis Ecclesiae, y que el número 29 aparece tachado mucho más tarde. Todo ello revela cómo San Ignacio, siempre fiel al pensamiento de que la Compañía no tuviera derecho jurídico de propiedad sobre cass y colegios, lejos de mitigar el primer plan, lo hizo aún más riguroso el año 1544, con ocasión sin duda de las ilustraciones conservadas en el Diario.

\footnotetext{
${ }^{71}$ Monumenta ignatiana, op. cit., 49-65 y Prolegomena LXVIII-LXXVI
} 
A este criterio de rigor responde el capítulo dedicado a la pobreza ${ }^{72}$, que comienza por la exposición de los motivos en que se funda la máxima austeridad, especialmente en la pobreza institucional, firme muro de la religión, defensa y reparo, que el enemigo de natura humana trata de debilitar a toda costa. San Ignacio no duda en aludir a las luces especiales recibidas por los primeros fundadores, y por lo tanto, por él mismo en este punto. Ello le mueve a instituir el voto de no alterar ni en la Congregación general ni de otro modo lo relativo a la pobreza en las Constituciones, a no ser tal vez para estrecharla $\left(n^{\circ} 1\right)$. De nuevo prescribe la incapacidad de las casas para recibir renta, ni siquiera para la sacristía. Y caso de que algún fundador quisiere dejar algo para la fábrica, que no disponga de ello la Compañía $\left(\mathrm{n}^{\circ} 2\right)$. Los profesos no pueden vivir en los colegios a no ser para trabajar en ellos $\left(n^{\circ} 3\right)$. En cuanto los colegios, que no necesiten del trabajo de los coadjutores, estos "no deberán residir en ellos, sino en Casas de la Compañía, como de los Profesos se ha dicho" (n $\left.{ }^{\circ} 4\right)$. Es decir que los colegios no son casas de la Compañía formada, o de los que están formados, sino de instituciones donde trabajan los de la Compañía para bien de los colegios. "No sólo rentas, pero ni possessiones algunas tengan las Casas o Iglesias de la Compañía, fuera de lo que para su habitación y uso necessario o conveniente fuese" $\left(\mathrm{n}^{0} 5\right)$. Cualquier cosa estable que reciba, debe ser vendida en la primera oportunidad para socorrer a las necesidades de los pobres de la Compañía o fuera della. Tales son las principales disposiciones relativas a la pobreza institucional de las casas. Siguen otras disposiciones respecto a la práctica individual de la misma.

La mente de san Ignacio parece suficientemente clara respecto de la incapacidad de la Compañía para poseer bienes rentables. Se ha aducido en contra de esta interpretación obvia y directa una objeción indirecta de la renuncia de la Congregación general segunda (decreto 33), suponiendo que en ella la Compañía no renuncia a la capacidad de poseer bienes estables, sino a la de poseer bienes estables de cuyas rentas pueda vivir la Compañía profesa. Tal interpretación no distingue la habitación y uso (que es algo funcional) y las cosas mismas sustantivas. El tener (habere) una habitación (disponible) en una casa no es poseer una habitación de la casa. Hay becas y oficios que dan derecho a habitación sin dar derecho alguno de propiedad. El derecho a poseer en propiedad no tiene fundamento en el texto del decreto ni en la concesión del Concilio tridentino. El tenor de ambos textos es como sigue:

"Concedít Sancta Synodus monasteriis et domibus tam virorum quam mulierum et mendicantium, exceptis domibus Fratrum Sancti Francisci Capuccinorum et eorum, quibus etiam aut ex

\footnotetext{
72 "Contituciones" 6, 2
} 
constitutionibus suis erat prohibitum, aut ex privilegio Apostolico non erat concessum, ut deinceps bona immobilia eis possidere liceat. Quod si alique loca ex praedictis quibus auctoritate Apostolica similia bona possidere permissum erat, eis spoliata sunt, eadem omnia illis restituenda esse decernit..."73.

La decisión de la Congregación segunda, decreto 33, es como sigue:

"Cum Conc. Tridentinum (...) facultatem dederit omnibus religosis, exceptis observantibus Minorum et Capuccinis, habendo bona immobilia in communi, non obstantibus quibuslibet Constitutionibus eorum; propositum fuit Congregationi, an restringendo paupertatem, placeret cedere iuri cuiqumque ad habenda bona immobilia in Domibus Professorum, quod ex decreto Concilii praedicto nobis esse acquisitum. Et placuit magno consensu Patribus, ut cederemus cuicumque iuri ex Concilio nobis provenienti: et iuxta nostrae Constitutiones et vota, quae post professionem emittuntur, paupertatem in Professis ac ipsorum domibus retineremus".

La uniformidad de los padres congregados, entre los que se hallaban además de Laínez, Nadal y los testigos más acreditados del pensamiento ignaciano, constituyen una prueba decisiva contra los que atribuyen a Nadal y otros jesuitas insignes del tiempo de san Ignacio, la doctrina de que la Compañía tiene la propiedad de los bienes estables de sus casas y colegios. Para entonces se habían fundado diversos colegios de la Compañía. Los padres congregados tenían experiencia personal del gobierno o superintendencia de aquellos colegios, gobernados por la Compañía, sin que fuera ella propietaria de los bienes patrimoniales del colegio.

Un caso notable de fundación modelo era el de la Universidad de Évora el año 1559. En sus preparativos habían intervenido, además del cardenal Infante y el general padre Laínez, los padres Miguel de Torres, Luis González de Cámara y Gonzalo Vaz de Melo. En la inauguración, el obispo de Évora en nombre del cardenal don Henrique, se levantó "con la preocupación del Cardenal en la mano, estando presente un notario apostólico, y entregó de parte de su Alteza la possessión de la Universidad a la Compañía en manos del Dr. P. Torres..."74.

\footnotetext{
${ }^{73}$ Concílio de Trento, sesión 25, c.3

${ }^{74}$ Carta del P. Baltasar Barrera, 27 de noviembre de 1559; MHSI, Litt. quadrim. 6, $392 \mathrm{~s}$
} 
En la bula Cum a nobis se explica el alcance de la frase entregar la possessión, que ha sido la piedra de escándalo para atribuir a san Ignacio y Nadal la doctrina de que la Compañía tomaba la propiedad de los bienes inmuebles de los colegios. En realidad, la Compañía sólo tomaba la carga de las clases y la parte disciplinar. La parte jurídica y la propiedad de los bienes quedaban en manos del cardenal Infante y de sus sucesores, quienes por su carácter real podrán ser sujetos del dominium altum propio del Estado. En realidad, la universidad y los colegios era personas morales autónomas, colegiales o no colegiales según se consideren como conjuntos de personas físicas integrantes de la universidad o como el conjunto de la dotación y de sus fines.

\section{La doctrina suareciana sobre la pobreza colectiva}

El 31 de agosto de 1592 escribía el general padre Aquaviva a Suárez y Molina exhortándoles a que defendieran el instituto de la Compañía contra los numerosos ataques de que era objeto. Molina comenzará el año siguiente la publicación de sus seis tomas De iustitia que le han dado renombre duradero entre los juristas. Suárez había explicado en Roma la misma materia, recientemente editada por Giers, y había explicado otras materias jurídicas como De bello. Una y otra le habían colocado ya entre los más famosos tratadistas de Derecho canónico y civil, aun veinte años antes de la publicación de su tratado De legibus. A 25 de octubre de 1593 escribía de nuevo Aquaviva a Suárez sobre el mismo encargo. Resultado de los trabajos de Suárez fueron los cuatro volúmenes De religione, en el último de los cuales se ocupa especialmente del instituto de la Compañía. Desde el generalato de Vitelleschi, que estudió con la mayor escrupulosidad la obra de Suárez, su escrito sobre el instituto es considerado como el comentario más clásico acerca de la Compañía. Hoy es preciso recordar estas circunstancias históricas de la obra suareciana, una vez que ha habido trabajos dirigidos a demostrar el desacuerdo doctrinal de Suárez con Nadal y posiblemente también con Laínez, para dejar como cosa probada en último término que san Ignacio dejó fundada la Compañía sobre la base de una doctrina incoherente en materia de pobreza.

Más aún, en una reciente publicación se ha tratado de demostrar con gran lujo de textos paralelos, que Suárez depende de Ribadeneira en numerosos pasajes relativos a la pobreza ${ }^{75}$. Es cierta la interdependencia entre Suárez y la obra de Ribadeneira Tratado en el cual se da razón del Instituto de la

\footnotetext{
${ }^{75}$ I. Gordon, Valores canónicos del P Ribadeneira, Granada 1932
} 
Compañía, como lo prueba la coincidencia de unos doscientos textos juridicos estudiados por Ignacio Gordon. También es cierto que Ribadeneira publicó este libro en 1605 veinte años antes que el volumen cuarto De Religione de Suárez. Pero no es menos cierto que Ribadeneira escribía en 1587 al cardenal Quiroga sobre las mismas materias sin que delate más conocimiento canónico que cinco bulas relativas a la Compañía. En otra, al mismo Quiroga, se han añadido por otra mano unas consideraciones canónicas sobre las rentas eclesiásticas, sin que aparezca por ningún lado la menor familiaridad con el derecho eclesiástico y el civil. Más aún, en la obra de 1605 incurre en deslices como considerar entre las consideraciones extravagantes el breve de Gregorio XIII Quum pro munere pastorali con otros descuidos que delatan no haber comprendido bien los apuntes de Suárez que estaba manejando. Lo único que se deduce de este incidente es que Ribadeneira, gran admirador de Suárez, acepta su doctrina como auténtica interpretación de san Ignacio. Ribadeneira estaba capacitado, tal vez como ninguno, para apreciar la fidelidad a los principios ignacianos de Suárez. Baste aquí esta indicación sumaria, que ampliamos en otro lugar.

La ventaja que Suárez lleva a Nadal y otros intérpretes ignacianos consistía principalmente en su clara idea acerca de la naturaleza de la propiedad de los bienes y de las personas eclesiásticas. En este punto halla Nadal dificultades nocionales y no precisamente prácticas, para cuya solución se había preparado Suárez desde los estudios jurídicos cursados antes de su entrada en la Compañía e iluminados más tarde por su visión filosófica y teológica del mundo.

Suárez divide en tres partes la cuestión de la pobreza de la Compañía en el tratado décimo De Religione, libro $4^{\circ}$. En los capítulos 4-8 explica la pobreza particular o individual de las personas. En los 9-10 explica la pobreza de las casas profesas, sometiendo a un análisis claro las diferencias entre la bula de Pablo III y la de Julio III, que es la definitiva. Según ella: "revera domus professa est capax alicuius dominii in communi, nimirum earum rerum mobilium quae ad actualem usum, habet (...). Idemque censendum est de dominio illius rei immobilis quae solum ad aliquam recreationem religiosis necessariam inserviat, non vero ad reditus et proventus, ex quibus religiosi sustentur" $" 76$.

A continuación añade Suárez una doble declaración, que responde a la distinción ente el dominio de propiedad y el dominio de jurisdicción, con el poder administrativo anejo a la jurisdicción.

${ }^{76}$ De instituto societatis lesu, IV c. 9, 1; 16, 745. El solum que destacamos nosotros contiene una limitación radical. El mero habitar es modo de usar, que puede ser en forma de huésped, sin ningún derecho más que el de ocupar un aposento, sin derecho a alquilarlo ni venderlo, como puede hacerlo el dueño cuando le parezca oportuno. 
"Quamvis autem horum bonorum dominium habeant professae domus, plenam autem administrationem non habent, sed in Praeposito Generali praecipue residet, propter perfectam subordinationem et monarchicum regimen, quod Societas profitetur, et ideo contractus, qui de his rebus in domibus professis non a conventu nec nomine eius, sed a Superiore nomine Generalis fiunt, tertia parte Constitutionum, cap. 3 n. 5 . Illorum autem redituum vel Bonorum immobilium, praeter ea quae dicta sunt, incapax est Societas professa (...) ita ut penes Societatem sit ulla eorum dispensatio".

En otras palabras, la Compañía en cuanto corporación jurídica no posee nada, aunque tiene el poder jurisdiccional y administrativo de las cosas muebles o inmuebles poseídas en propiedad dentro de ciertos límites por cada una de sus casas, iglesias u sacristías para sí, no para la Compañía ni para otras casas. Éstas en cambio carecen de todo poder jurisdiccional y administrativo, el cual está en poder de la Compañía y sus superiores jerárquicamente. El dominio de propiedad y el dominio de jurisdicción no pueden estar separados con más precisión ni acomodación más perfecta a la distinción que hemos visto en la Iglesia entre ambas clases de dominio. Adviértase que, al hablar de la Compañía, se la entiende siempre en forma de persona colegial o corporación, mientras que las casas, templos, sacristías, etc., son personas no colegiales o pías obras fundacionales, conforme a la definición de G. Michiels arriba copiada.

Al hablar de los colegios en el capítulo 11, Suárez, formula una advertencia capital sobre la heterogeneidad de los miembros de que está constituída la Compañía.

"Quamvis ex collegiis et utriusque domibus probationis et professis unum corpus Societatis coalescat, nihilominus non eodem modo paupertatem in communi observant; sunt enim quasi membra heterogenea unius corporis organici (...). Principio igitur supponendun est collegia Societatis non profiteri paupertatem in communi, nec quod bona mobilia, nec quod reditus et bona stabilia, sed illorum esse capacia, imo sine illis admitti aut fundari non debere, quamtum sufficiant ad moderatam sustentationem religiosorum in eo numero, qui pro qualitate et ministeriis ac religiosa disciplina uniuscuisque collegii sint, iuxta intentionem Concilii Tridentini sess. 25 de Regular. c. 3; constat autem haec institutio Societatis quod hanc partem ex Constitutionibus eius et Bullis Pontificiis; in Examine 
enim sic habetur, c. 1 n. 4: Habebit Societas Collegia et domus probationis reditibus dotatas. Et quarta parte c. 2, n. 5, et sexta parte, c. 2, lit. A et in Bullis Pauli III et Julii III: Possint (dicitur) habere (...) collegia habentia census, reditus".

En efecto, así tenían en Evora dos colegios universitarios, dirigidos por la misma comunidad de la Compañía.

La heterogeneidad del cuerpo de la Compañía imita la heterogeneidad de la Iglesia en la multitud de las instituciones, todas ellas dependientes de la Iglesia y constituidas por ella. Tanto en la Compañía, como en la misma Iglesia que es su modelo, deben distinguirse las siguientes personas morales o institucionales esencialmente distintas e inconfundibles:

$1^{\circ}$. Personas colegiales constituídas por personas físicas. Así es la Iglesia cuyos miembros están unidos por el Espíritu Santo, y la Compañía cuyos miembros están unidos por la Iglesia, y mediante ella o en ella por el Espirítu Santo, para servir a Dios y a la Iglesia. Son capaces de jurisdicción las personas, pero no de dominio de propiedad por sí mismas, aunque sí en sus instituciones subordinadas. La Compañía tiene la autoridad ordinaria expuesta en la parte novena, capítulo cuarto.

$2^{\circ}$. Personas colegiales, incapaces de jurisdicción, pero capaces de dominio de propiedad, como son los seminarios, es decir rector, claustros, alumnos, dependientes del todo de sus obispos, capaces de bienes muebles e inmuebles sin limitación, con tal de que no sean superfluos.

$3^{\circ}$. Personas no colegiales, capaces de derechos y de obligaciones más o menos limitados: iglesias, seminarios, hospitales, sacristías, dote de colegios en bienes muebles o inmuebles, raíces o no raíces, obras pías y fundaciones. Estas instituciones (no siempre personales) han de ser administradas por las personas físicas o colegiales capaces de jurisdicción eclesiástica (no por seglares) o por sus representantes, como son el Papa, los obispos y los superiores religiosos.

Tanto san Ignacio como Suárez coinciden en la distinción e inconfundibilidad de estas instituciones así en la Iglesia como en la Compañía, aunque admitiendo que dentro de la Iglesia existan monasterios, provincias religiosas canónicamente erigidas y congregaciones capaces de ser al mismo 
tiempo sujetos de jurisdicción y de dominio de propiedad. Por eso San Ignacio en los cómodos y razones para no tener cosa de renta, aparte de otras razones de piedad cristiana y afecto a Cristo, dice en una razón: "3. Parece que con mayor afecto se une con la Iglesia, siendo uniformes en no tener cosa alguna, considerando en el Sacramento a Cristo pobre". "15. Está eligiendo todos diez nemine discrepante tomamos por Cabeza al mismo Jesús nuestro Creador y Señor, para ir debajo de su bandera para predicar y exhortar, que es nuestra profesión. "16. De esta manera nosotros pidiendo, nos fué concedida la Bula, y después, esperando la expedición por un año, y perseverando el mismo asensu nos fué confirmada por Su Santidad". "17. Propio es de Dios nuestro Señor ser inmutable; y del enemigo, mutable y variable". Se refiere a la bula de Pablo III.

Posteriormente hubo un momento de vacilación al recibir las rentas para la iglesia de Nuestra Señora de la Estrada, san Ignacio formuló varias razones para recibir aquellas rentas para la iglesia, y dice: "8. Después que dos de la Compañía vieron la materia, aprobaron todos los otros" "77. Pero en el Diario dice el 6 de febrero "ser confusión tener en parte, el tener todo un escándalo y un deprimir la pobreza que Dios nuestro Señor tanto alaba".

El escándalo del tener la Compañía bienes había que extirparlo a todo trance. Para ello vino el voto de restringenda magis paupertate.

Suárez coincide con san Ignacio, aunque matizando el pensamiento en tres quaestiones: "Quaestio decima tertia: An res sacrae et sacratae Deo possint esse materia humani dominii. Quaestio quarta decima: An reditus ecclesiastici sint materia humani dominii et quo titulo ad sacerdotes pertineant. Quaestio quinta decima: An res quaelibet immobiles et sacrae cadant sub humanum dominium et cuiusmodi".

Como base de su doctrina de los bienes sagrados y consagrados, como dijimos, defiende que pueden ser de las comunidades (p. 39) sobre los bienes materiales. Suárez hace un resumen histórico de la propiedad eclesiástica en los primeros siglos. Hasta el pontificado de Urbano I (222-230) los fieles vendían sus bienes para repartir el producto en la vida común y en limosnas a los pobres. La administración estaba reservada a los apóstoles, obispos y diáconos. La Iglesia no tenía, por lo tanto, bienes muebles ni rentas. Esta nueva costumbre comenzó, según Suárez, con Constantino. Los fieles daban grandes fincas, y aun ciudades, a las iglesias, dando origen a las rentas eclesiásticas, que según unos pertenecen sólo al patrimonio de Cristo y según otros admiten también dominio humano. Suárez cree que en la Iglesia ha habido diversas disciplinas. El colegio apostólico era pobre. Con

${ }^{77}$ Mon. Ignat. Ser. III pp. 78-81 
el tiempo los fieles fueron formando o reteniendo haciendas particulares, y finalmente los mismos bienes eclesiásticos se dividieron en las cuatro porciones clásicas de la Edad Media: una para la Iglesia, otra para los pobres, la tercera para el clero y la cuarta para el obispo ${ }^{78}$. La Iglesia, por lo tanto, originariamente es pobre y los obispos son los administradores natos de los bienes inmuebles eclesiásticos: "Horum bonorum administratio et fere possessio et usus ad ecclesiasticas spectat personas"79. La Iglesia, como tal, no aparece en esta exposición como propietaria de bienes eclesiásticos. Aunque los pueda adquirir, los aplica al sostenimiento de las obras pías, a pobres y personas eclesiásticas.

\section{Conclusiones}

La doctrina de san Ignacio y de Suárez se acomoda fielmente a las normas y principios siguientes de la tradición de la Iglesia:

$1^{\circ}$ La propiedad eclesiástica, cuando proviene de renuncias resulta, de la intención del donante y de la aceptación divina. Si la intención es imprecisa por parte del donante, debe ser precisada conforme a la ley. Una vez concretada debidamente la intención, la donación es aceptada por Dios y los bienes se incorporan en forma permanente al patrimonio de Cristo, según la definición de Michiels.

$2^{\circ}$ Por consiguiente la donación no puede ser dividida ni modificada per se contra la voluntad del donante por intervención humana secular, ni eclesiástica.

$3^{\circ}$ La intención del donante de bienes estables aceptada por Dios, y solamente reconocida por la Iglesia, da por resultado la creación canónica de personas morales no colegiales que tienen las propiedades y derechos inviolables de los minorennes.

$4^{\circ}$ El carácter objetivo y permanente de los bienes eclesiáticos inmuebles, que por su naturaleza deben estar destinados de algún modo al bien común, excluye la posibilidad de que, por razones de bien mayor, sean conculcados sus derechos por divisiones, modificaciones o translaciones que no se

${ }^{78}$ Cfr. J. Giers, pp. 48ss. Es interesante advertir el interés de Suárez por seguir la línea histórica de la pobreza evangélica y religiosa, que divide en dos fases: la primera abarca la Iglesia primitiva, compuesta de gente pobre y sin aspiraciones a intervenir en la sociedad; la segunda comienza en el siglo III; la Iglesia, como concede Orígenes, cuenta entre los fieles muchos ricos y altos personajes, que representan un papel social prestigioso; de ahí el cambio de la organización del diaconado, que se adapta al régimen de la propiedad, cfr. Orígenes, Contra Celsum III, 9, cfr. MHSI, cit.71

${ }^{79} \mathrm{Cfr}$. MHSI, cit. 74 
verifiquen en utilidad evidente de los mismos bienes institucionales y en forma canónicamente regulada.

$5^{\mathrm{o}}$ Tanto los concilios y legislaciones canónicas, como la aplicación de los mismos a la Compañía, condenan con las más graves censuras toda perturbación de los bienes eclesiásticos, como ocasión de toda impiedad e injusticia.

$6^{\circ}$ Las personas colegiales que profesan la pobreza evangélica, aunque sean incapaces de poseer por sí mismas, si son personas heterogéneas (como lo es la Iglesia, y a su ejemplo la Compañía) pueden adquirir bienes para las personas no colegiales subalternas, como son las pías fundaciones, universidades y colegios.

$7^{\circ}$ La pobreza colectiva, propia de personas colegiales $u$ órdenes no centralizadas, no es compatible con el dominio de propiedad pero sí con el dominio de jurisdicción. Ni en la Iglesia universal ni en la Compañía recaen en el mismo sujeto ambos dominios.

$8^{\circ}$ La doctrina de la Iglesia, tal como la interpretan san Ignacio y Suárez, es al mismo tiempo institucionalista y funcionalista, en un sentido que supera lo institucional y lo funcional del derecho positivista. Se trata de una institución carismática, donde el hombre y sus bienes son mero instrumento de Dios, causa principal tanto de la creación de esas instituciones como de su función. La espiritualidad ignaciana y el pensamiento suareciano tienen por ideal el llegar a ser meros instrumentos divinos, reconociendo que hay otros caminos en la Providencia del Señor. 